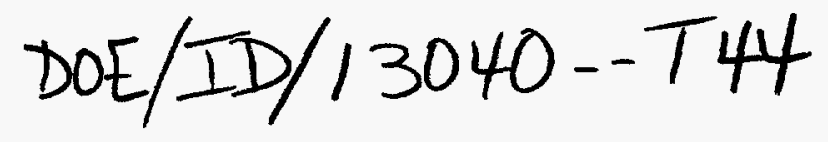

\title{
AQUACULTURE INFORMATION PACKAGE
}

Prepared For:

\author{
U.S. Department of Energy \\ Idaho Operations Office \\ 785 DOE Place \\ Idaho Falls, ID 83401
}

Contract No. DE-FG07-90ID 13040

By:

Tonya Boyd

Kevin Rafferty, P.E.

Geo-Heat Center

Oregon Institute of Technology

3201 Campus Drive

Klamath Falls, OR 97601

DISTRIBUTION OF THIS DOCUMENT IS UNLIMTED

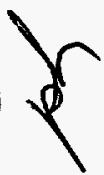




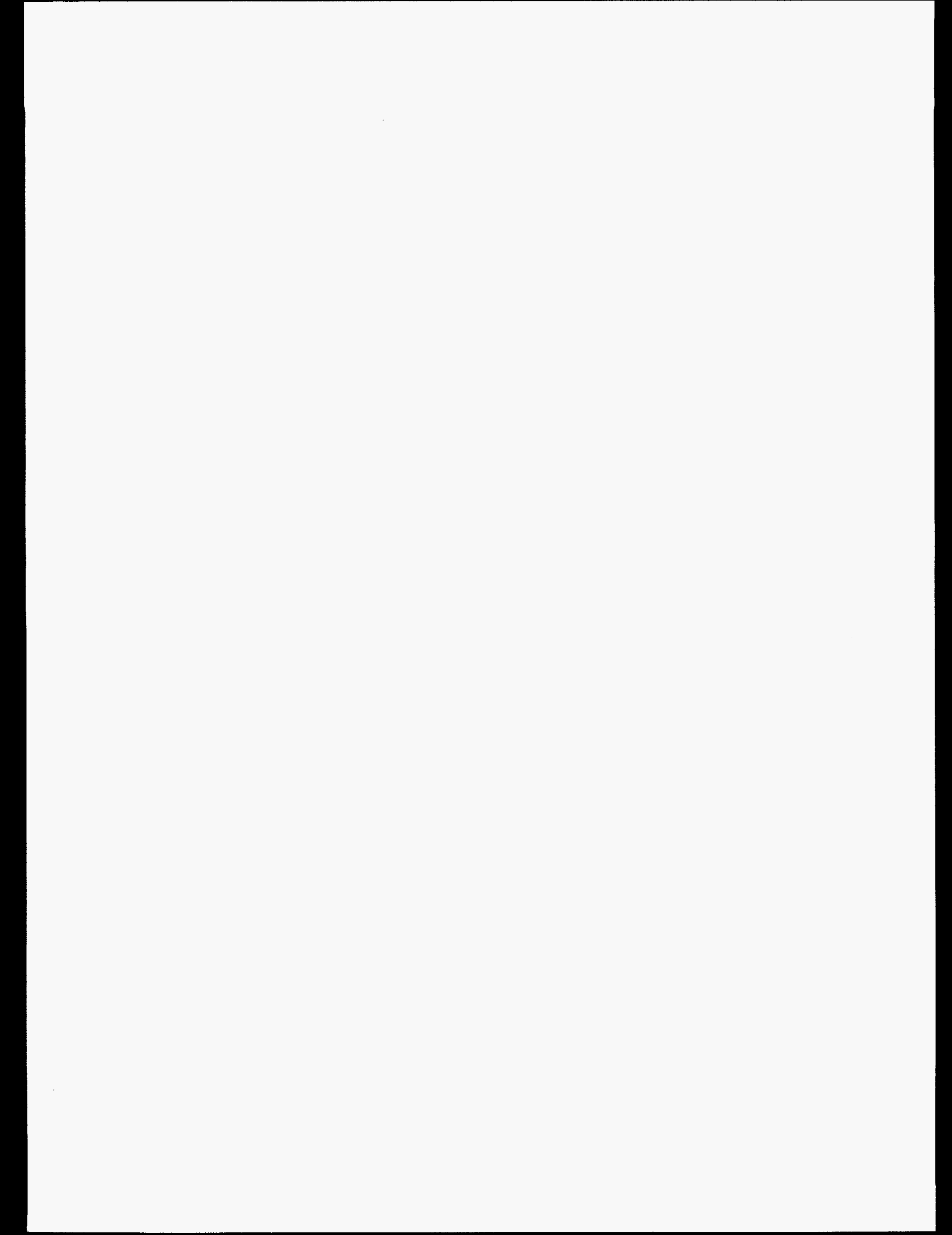




\section{DISCLAIMER}

This report was prepared as an account of work sponsored by an agency of the United States Government. Neither the United States Government nor any agency thereof, nor any of their employees, makes any warranty, express or implied, or assumes any legal liability or responsibility for the accuracy, completeness, or usefulness of any information, apparatus, product, or process disclosed, or represents that its use would not infringe privately owned rights. Reference herein to any specific commercial product, process, or service by trade name, trademark, manufacturer, or otherwise does not necessarily constitute or imply its endorsement, recommendation, or favoring by the United States Government or any agency thereof. The views and opinions of authors expressed herein do not necessarily state or reflect those of the United States Government or any agency thereof. 


\section{DISCLAIMER}

Portions of this document may be illegible electronic image products. Images are produced from the best available original document. 


\section{DISCLAIMER STATEMENT}

This report was prepared with the support of the U.S. Department of Energy (DOE Grant No. DE-FG07-90ID 13040). However, any opinions, findings, conclusions, or recommendations expressed herein are those of the author(s) and do not necessarily reflect the view of DOE. 


\section{INTRODUCTION}

\section{SECTION 1 - MARKET AND PRICE INFORMATION}

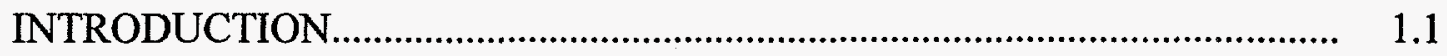

CATFISH MARKET AND PRICE INFORMATION ........................................ 1.1

TILAPIA MARKET AND PRICE INFORMATION ........................................ 1.8

REFERENCES........................................................................................ 1.9

SECTION 2 - WATER QUALITY ISSUES IN AQUACULTURE

INTRODUCTION ................................................................................. 2.1

TEMPERATURE..................................................................................... 2.1

DISSOLVED OXYGEN............................................................................. 2.1

NITROGENOUS WASTES.......................................................................... 2.1

pH.

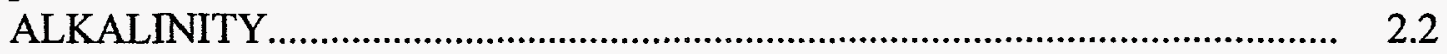

HARDNESS.

CARBON DIOXIDE

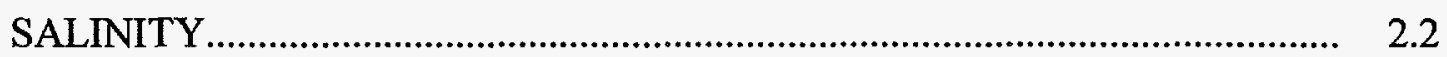

CHLORINE ........................................................................................ 2.3

HYDROGEN SULFIDE.............................................................................. 2.3

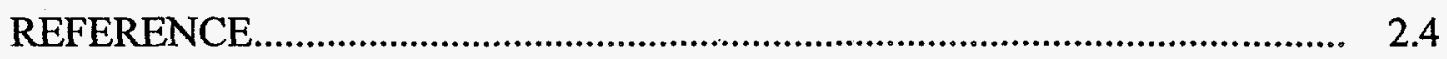

\section{SECTION 3 - CULTURE INFORMATION}

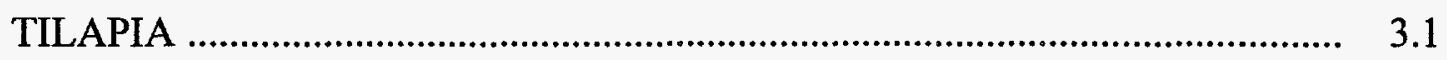

Flow-Through Systems............................................................................. 3.1

Recirculating Systems................................................................................. 3.2

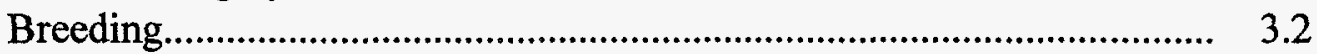

Production Management............................................................................. 3.3

Oreochromis Aureus................................................................................. 3.3

Oreochromis Mossambicus..................................................................... 3.3

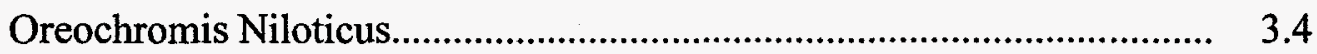

Tilapia Rendalli.............................................................................. 3.4

Tilapia Zilli................................................................................... 3.4

CHANNEL CATFISH................................................................................ $\quad 3.5$

Brood Stock ........................................................................................ 3.6

Spawning........................................................................................... 3.6

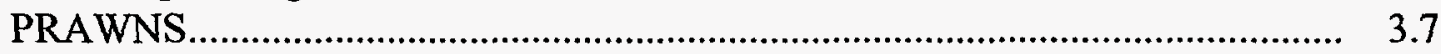

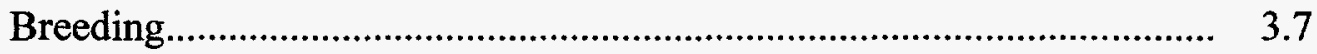

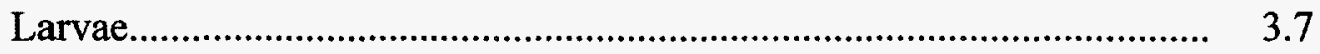


Postlarvae.

Adult.

Stocking of Juveniles.

Feeding

Water Quality Management.

REFERENCES

\section{SECTION 4 - POND AND RACEWAY HEAT LOSS CALCULATIONS}

INTRODUCTION.

TEMPERATURE REQUIREMENTS FOR SELECTED SPECIES

HEAT EXCHANGE PROCESSES.

Evaporative Loss.

Convective Loss.

Radiant Loss.

SURFACE COVER

POND ENCLOSURE

THERMAL MASS.

FLOW REQUIREMENTS

REFERENCES

\section{SECTION 5 - AQUACULTURE BIBLIOGRAPHY}

AQUACULTURE - GENERAL ................................................................ 5.1

BIOECONOMICS/ECONOMICS.................................................................. 5.1

CULTURE SYSTEMS - PONDS............................................................... 5.2

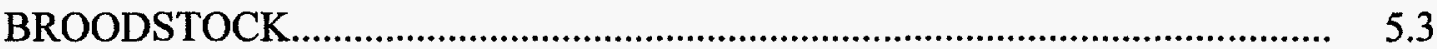

AMERICAN EEL .

AMERICAN LOBSTER ……............................................................... 5.4

CHANNEL CATFISH............................................................................. 5.4

FRESHWATER PRAWNS...................................................................... 5.4

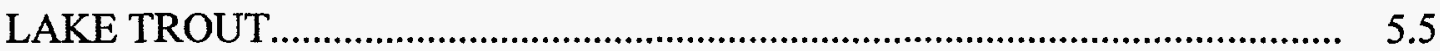

PINK SHRIMP (Pennaeus Dourarum) .................................................................. 5.6

STRIPED BASS..................................................................................... 5.6

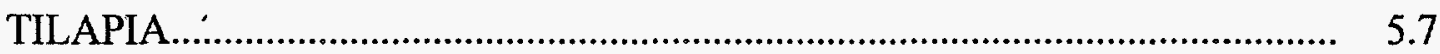

SECTION 6 - AQUACULTURE GLOSSARY ....................................................... 6.1

\section{SECTION 7 - STATE/REGIONAL/UNIVERSITY/EXTENSION} AQUACULTURE OFFICES

EXTENSION CONTACT IN AQUACULTURE............................................... 7.1 FEDERAL FISHERY ASSISTANCE OFFICES.............................................. 7.4 ADDITIONAL SOURCES OF INFORMATION FOR AQUACULTURISTS... $\quad 7.5$ REGIONAL AND STATE AQUACULTURE ASSOCIATIONS........................ $\quad 7.6$ 
STATE AQUACULTURE COORDINATORS

DIAGNOSTIC SERVICES AVAILABLE.

SEA GRANT PROGRAM ABBREVIATIONS AND ADDRESSES.

SECTION 8 - STATE AQUACULTURE PERMIT REQUIREMENTS 


\section{AQUACULTURE INFORMATION PACKAGE}

\section{INTRODUCTION}

This package of information is intended to provide background information to developers of geothermal aquaculture projects. The material is divided into eight sections and includes information on market and price information for typical species, aquaculture water quality issues, typical species culture information, pond heat loss calculations, an aquaculture glossary, regional and university aquaculture offices and state aquaculture permit requirements.

Section 1 - Market and Price Information contains information on the current status of the catfish and tilapia markets in the U.S. For the catfish market, information is provided on both national and state production, pond acreage, type of production and end market served. Tilapia data presented in the section includes national and regional production figures, current price data and a brief summary of the international import volume.

Section 2 - Water Quality Issues in Aquaculture contains an introduction to the major water quality issues for aquaculture in general and explains the importance of major water quality parameters.

Section 3 - Culture Information presents information on breeding, management, feeding and harvest of typical tilapia and catfish sub-species, and prawns.

Section 4 - Pond and Raceway Heat Loss Calculations provides an introduction to the methods used in calculations of heat losses from aquaculture facilities. Procedures for calculating the geothermal flow requirements for a project are provided.

Section 5 - Aquaculture Bibliography provides a list of useful aquaculture references in the areas of general aquaculture, economics, culture systems and individual species.

Section 6 - Aquaculture Glossary define typical terms used in the aquaculture industry.

Section 7 - State/Regional/University/Extension Aquaculture Offices provides contact information for a variety of technical experts who may be of use to the aquaculture developer.

Section 8 - State Aquaculture Permit Requirements summarizes the permits which may be required for the operation of a commercial aquaculture facility in the states of, Arizona, California, Colorado, Idaho, Montana, Nevada, New Mexico, Oregon, South Dakota, Utah, and Washington. 
SECTION 1 - MARKET AND PRICE INFORMATION 


\section{Section 1 \\ MARKET AND PRICE INFORMATION}

\section{INTRODUCTION}

The Economic Research Service, U.S. Department of Agriculture (Washington DC 200365831) publishes a biannual report entitled Aquaculture Outlook. The following information was taken from the March 1998 version of that reference.

Over the past 10 years the average per capita fish and seafood consumption has remained relatively flat, at around 15 pounds per year, roughly 2 to 3 pounds less than turkey consumption. During this time period, the source of seafood products has been shifting away from wild harvest and towards aquaculture. With about 20 percent of U.S. fish and seafood consumption now being farm-raised, aquaculture is becoming a recognized segment of the livestock complex, larger than veal, mutton and lamb combined. In 1997, U.S. annual production of processed catfish products was approximately 1 pound per capita, imports of farm-raised shrimp was likely over 1 pound per capita, and the combination of farm-raised salmon, trout, tilapia, crawfish, and other aquaculture products probably added another pound.

A number of major trends in 1998 are expected to effect the domestic aquaculture industry. First, there should be large supplies of competing meats, especially pork and chicken, available. Second, prices for catfish, the largest segment of the domestic aquaculture industry, are expected to increase as available supplies tighten. Third, with the devaluation of their currencies versus the dollar, the United States market should become more attractive to Asian seafood imports.

\section{CATFISH MARKET AND PRICE INFORMATION}

The following information was taken from the following publications Aquaculture Outlook, March 1998, and Catfish Production, February 1998.

Based on grower inventories reported for January 1 , catfish sales by growers to processors in 1998 are forecast to expand to 535-545 million pounds, up 2-4 percent, after increasing 11 percent in 1997. Most of that growth is expected to come in the first and fourth quarters. In the second and third quarters, supplies are expected to tighten, due to a 20-percent decrease in inventories for stockers, and prices paid to farmers should strengthen. Falling farm prices in 1997 resulted in growers cutting back on inventories. The much smaller increase in production expected in 1998, combined with a strong domestic economy, is expected to put some upward pressure on both farm and processor prices, especially in the middle of the year. Sales to processors in January 1998 were 47 million pounds, up 10 percent, despite lower food-size inventories at the start of the year. Sales are expected to run about 5 percent above a year earlier through the first quarter, normally the strongest sales period. 
With a forecast of continued economic growth in the domestic economy in 1998, strong demand is anticipated from the restaurant and food service sectors. In 1995, the national Marine Fisheries Service estimated that restaurant and food service sales accounted for over two-thirds of all seafood sales. A strong demand picture combined with only slightly higher catfish production is expected to strengthen farm prices somewhat in 1998. After 3 years of farm prices running between 77 to 79 cents a pound, prices dropped to 71.2 cents in 1997, down 8 percent from a year earlier. Grower prices ended 1997 at 69 cents a pound, but in 1998 they are expected to strengthen in the second and third quarters as supplies of market size fish decline. Table 1 shows the total round weight (whole fish) processed and the price paid to producers from 1983 to 1997.

Table 1. Total Round Weight Processed and Price Paid to Producers, 1983 - 1997

\begin{tabular}{|c|c|c|}
\hline Year & $\begin{array}{c}\text { Total Round Weight } \\
\text { Processed }\end{array}$ & $\begin{array}{c}\text { Total Price Paid to } \\
\text { Producers }\end{array}$ \\
\hline & 1,000 Pounds & Cents/Pound \\
\hline 1983 & 137,250 & 61.1 \\
1984 & 154,255 & 69.3 \\
1985 & 191,616 & 72.5 \\
1986 & 213,756 & 66.8 \\
1987 & 280,496 & 61.7 \\
1988 & 295,109 & 76.4 \\
1989 & 341,900 & 71.5 \\
1990 & 360,435 & 75.8 \\
1991 & 390,870 & 63.1 \\
1992 & 457,367 & 59.8 \\
1993 & 459,013 & 70.9 \\
1994 & 439,269 & 78.4 \\
1995 & 446,886 & 78.6 \\
1996 & 472,123 & 77.3 \\
1997 & 524,949 & 71.2 \\
\hline
\end{tabular}

Growers reported starting 1998 with about eight percent lower inventories of food-size fish, and processors' inventories are also down slightly from the same time the previous year. However, the expected lower prices for pork and chicken products in first-half 1998 may tend to blunt any strengthening in catfish prices. Prices for hogs are expected to average over a third lower in the firsthalf of 1998 compared with a year earlier, and wholesale chicken prices are expected to decline about 7 percent. 
There is also the possibility of lower prices for imported seafood items from Asia such as tilapia and shrimp products. The currencies of Thailand and Indonesia, both major seafood exporters of the United States, have fallen considerably versus the dollar since third-quarter 1997.

The total number of operations on January 1,1998 in the 15 selected states was 1,224, down seven percent from the January 1, 1997 total of 1,319, as shown in Table 2. The number of operations in the top producing states (AL, AR, LA, and MS), also, decreased seven percent from January $1,1997$.

Catfish growers in the 15 selected states had sales of 422 million dollars during 1997. These sales were down one percent from the 1996 total of 425 million dollars. Sales of all foodsize fish totaled 402 million dollars, down fractionally from last year's total of 403 million dollars. Sales of fingerlings and fry totaled 15.4 million dollars, compares with 16.1 million dollars in sales during 1996. Sales of stockers totaled 4.03 million dollars, down 16 percent from the 4.81 million dollars in sales during 1996. Sales of broodfish previously used for breeding totaled 476 thousand dollars, compared with 383 thousand during 1996.

Table 2. By State, Number of Operations and Water Surface Acres, Used for Production, 1997-98 and Total Sales, 1996-97

\begin{tabular}{|c|c|c|c|c|c|c|}
\hline \multirow[b]{3}{*}{ State } & \multicolumn{2}{|c|}{$\begin{array}{c}\text { Number of operations on } \\
\text { Jan } 1\end{array}$} & \multicolumn{2}{|c|}{$\begin{array}{c}\text { Water Surface Acres Used for } \\
\text { Production During Jan } 1 \text { - } \\
\text { Jun } 30\end{array}$} & \multicolumn{2}{|c|}{ Total Sales } \\
\hline & $1997_{1}$ & 1998 & $1997_{1}$ & 1998 & 1996 & 1997 \\
\hline & \multicolumn{2}{|c|}{ Number } & \multicolumn{2}{|c|}{ Acres } & \multicolumn{2}{|c|}{ 1,000 Dollars } \\
\hline$\widehat{A L}$ & 245 & 235 & 21,000 & 21,800 & 52,795 & 53,740 \\
\hline AR & 180 & 165 & 28,500 & 27,000 & 52,214 & 50,480 \\
\hline CA & 50 & 64 & 2,400 & 2,300 & 6,873 & 8,225 \\
\hline FL & 12 & 14 & 100 & 150 & 148 & 352 \\
\hline KY & 20 & 18 & 280 & 140 & 517 & 905 \\
\hline LA & 108 & 101 & 14,300 & 13,500 & 27,838 & 30,783 \\
\hline MS & 360 & 331 & 102,000 & 100,000 & 274,559 & 265,934 \\
\hline MO & 65 & 60 & 2,400 & 1,900 & 1,746 & 2,022 \\
\hline NC & 60 & 53 & 1,400 & 1,300 & 2,466 & 2,194 \\
\hline OK & 35 & 25 & 550 & 450 & 376 & 385 \\
\hline Sc & 25 & 20 & 1,200 & 1,100 & 3,223 & 2,833 \\
\hline TN & $19^{\circ}$ & 19 & 290 & 280 & 284 & 327 \\
\hline TX & 74 & 57 & 1,900 & 2,000 & 936 & 2,244 \\
\hline $\begin{array}{l}\text { Other } \\
\text { States }\end{array}$ & 66 & 62 & 1,140 & 1,090 & 1408 & 1319 \\
\hline TOTAL & 1319 & 1224 & $\frac{1,17,460}{177,400}$ & $\frac{1,000}{173,010}$ & $\frac{1,400}{425,383}$ & $\frac{1,319}{421,743}$ \\
\hline
\end{tabular}

1. Revised 
Growers reported that as of January 1,1998 , they anticipate 173,010 acres of ponds will be in use during the first-half 1998 . This total is down three percent (3,500 acres) from the previous year (Table 2), which saw a large increase in acreage. Growers also noted that they plan on renovating or constructing about 8,300 acres of ponds. Of the total acres, 6,560 are to be renovated during the period of January 1, 1998 to June 30, 1998. An additional 1,790 acres are under construction or expected to be constructed and in use by July 1,1998. This estimate is only about a third of what it was for the first half of 1997, reflecting falling farm level catfish prices in 1997. Most of the acreage decrease was in the four largest producing states, Mississippi, Arkansas, Alabama, and Louisiana. The number of growers in these states was also down and the trend towards smaller numbers of larger farms is expected to continue as growers look for economics of size in larger operations. Growers are looking towards spreading the costs of specialized equipment over larger overall production to lower their average production costs.

During the period of July 1, 1997 through December 31, 1997, 3,343 acres were taken out of production. As of January 1, 1998, 6,177 acres were being used for broodfish production, 138,700 acres were being used for foodsize production and 21,960 acres were being used for fingerling production (Table 3).

Table 3. Intended Utilization of Water Surface Acres During Jan - Jun 30, 1998

\begin{tabular}{|l|c|c|c|}
\hline \multirow{2}{*}{ State } & \multicolumn{3}{|c|}{ Intended Utilization During January 1 - June 30 } \\
\cline { 2 - 4 } & For Broodfish & For Foodsize & For Fingerlings \\
\hline AL & 590 & 18400 & 1900 \\
AR & 750 & 21200 & 4200 \\
CA & 90 & 1900 & 270 \\
FL & 30 & 35 & 70 \\
KY & 5 & 110 & N/A \\
LA & 360 & 11700 & 1400 \\
MS & 3800 & 80400 & 12400 \\
MO & 60 & 880 & 530 \\
NC & 50 & 1000 & 170 \\
OK & 50 & 240 & 95 \\
SC & 60 & 840 & 200 \\
TN & 25 & 225 & 30 \\
TX & 180 & 1200 & 430 \\
Other States & 127 & 570 & 265 \\
\hline TOTAL & 6177 & 138700 & 21960 \\
\hline
\end{tabular}

Total sales by catfish farmers in 1997 fell one percent to $\$ 422$ million. Revenues from sales of food-size fish, stockers, and fingerlings were all lower. The poundage of food-size fish increased strongly (up seven percent from 1996), but the poundage of stocker and fingerlings sales were both down. Farmers reported total sales of food-size fish were a record 563 million pounds, but the higher poundage was offset by the eight-percent decrease in prices, from 77 to 71 cents per pound 
as shown in Table 4. Grower sales of food-size fish to processors accounted for 525 million pounds, so the remaining 38 million pounds were sold through other channels, such as directly to consumers or restaurants, or to brokers or wholesalers. The lower poundage of stockers and fingerlings sales helped to hold up their prices. Average unit prices for both size classes showed no change between 1996 and 1997.

With lower inventories in most size classes reported for the beginning of 1998 and a strong domestic economy, prices for food-size fish are expected to move slowly upward. If this happens then the prices for stockers and fingerlings should also show some upward strength. However, for food-size fish the impact of lower supplies may not be felt until the second quarter. Another factor that could put additional upward price pressure on smaller fish would be if corn and soybean prices move lower and these declines result in reduced feed costs. If feed prices decline, growers may increase feeding rates to attempt to get their smaller fish to market size sooner.

Grower-held inventories at the start of 1998 , in terms of numbers of fish, were down for large and medium food-size fish, but up fractionally for small food-size fish. The smaller inventories of food-size fish are expected to reduce the supplies of fish over the first several months of 1998 and to exert some upward pressure on prices. Processors may be growing more sensitive to changes in supplies as their monthly ending inventories have been becoming a smaller percentage of their monthly processing volume.

Table 4. Weight and Average Value of Sales of All Foodsize by Sale, 1996-97

\begin{tabular}{|lcccc|}
\hline & \multicolumn{2}{c}{ Pounds Sold } & \multicolumn{2}{c|}{ Avg. Value per Pound } \\
State & $\mathbf{1 9 9 6}$ & $\mathbf{1 9 9 7}$ & $\mathbf{1 9 9 6}$ & $\mathbf{1 9 9 7}$ \\
\hline AL & 72,692 & 77,416 & 0.71 & 0.68 \\
AR & 57,680 & 65,000 & 0.76 & 0.7 \\
CA & 3,750 & 4,452 & 1.76 & 1.77 \\
FL & 14 & N/A & 0.43 & N/A \\
KY & 495 & 672 & 1.02 & 1.3 \\
LA & 38,000 & 45,000 & 0.71 & 0.67 \\
MS & 344,480 & 360,000 & 0.77 & 0.71 \\
MO & 1,388 & 1,504 & 0.74 & 0.76 \\
NC & 2,802 & 2,524 & 0.79 & 0.75 \\
OK & 215 & 224 & 0.93 & 0.86 \\
SC & 2,898 & 2,646 & 0.94 & 1.01 \\
TN & 123 & 235 & 1.81 & 1.21 \\
TX & 689 & 2,062 & 0.99 & 0.94 \\
Other States & 1,050 & 834 & 1.13 & 1.27 \\
\hline TOTAL & 526,276 & 562,569 & 0.77 & 0.71 \\
\hline
\end{tabular}

In the first quarter of 1997 , farm sales to processors were 136 million pounds with an average farm price of 73 cents a pound. In 1998, the first quarter volume is expected to be higher and prices, while likely to show some strength for late 1997 levels, are expected to average lower, around 70 to 71 cents a pound. 
At the beginning of 1998, growers reported that the number of fish in inventory in the stocker class, those fish weighing from 0.06 to 0.75 pound, were down 19 percent, but the number of fingerlings, fish below 0.06 pound, were 18 percent higher than the previous year. While many of the stockers will likely achieve market size during first-half 1998, most of the fingerlings will not be ready for market until the latter part of the year. If processor demand remains strong during the second and third quarters, there could be periods of reduced supplies of food-size fish before the fingerlings in inventory at the start of the year achieve market weight.

Aside from fingerlings, the only area where catfish growers indicated that their inventories increased was for broodfish stocks. The number of broodfish rose two percent to 1.19 million fish. However, the estimated weight of these broodfish was up less than one percent from 1997. The total egg production is a function of body weight, so the two percent increase in the number of broodstock in inventory is probably less significant than the very small decrease in the overall body mass of broodfish. This implies that 1998 production of fingerlings and stockers is expected to be roughly the same as in 1997.

Processor sales rose in 1997 for the third consecutive year. After increasing five percent in 1996, sales were up an additional 10 percent to 262 million pounds in 1997 . The increase in processor sales was enough to offset a four percent decrease in overall processor prices. This was the second year in a row that overall processor prices have declined. Gross processor revenues in 1997 increased by just over $\$ 30$ million to $\$ 591$ million. This suggests that the demand for catfish over the last several years has been relatively elastic, at least at wholesale levels. Processor prices were lower throughout 1997, compared with a year earlier, and were the weakest during the summer months when sales volumes were posting their strongest gains. In 1998, gross processor revenues are again expected to increase as a small increase in sales volumes combines with slightly higher prices.

Processor sales had very few weak spots in 1997. The only category where sales declined was for frozen whole fish, but this category only accounted for five percent of processor sales. Sales of both fresh and frozen product were at record levels, posting double-digit increases in 1997. Much of the growth in catfish sales in the coming years is expected to come from fillets and other prepared products. First, many chain restaurants and food services now use portion-controlled products ready to cook. Second, with increasing time pressure, many U.S. consumers are also looking for fully prepared products. In 1998, processor sales are expected to expand, but prices are expected to be under competitive pressure from other seafood products and meat products.

Direct sales to processors accounted for 94 percent of the total sales of foodsize fish as shown in Table 5. Eighty-two percent of the stocker sales were to other producers. 
Table 5. Foodsize Percent Sold by Outlet Type by State, 1997

\begin{tabular}{|l|c|c|c|c|c|}
\hline State & Livehauls & $\begin{array}{c}\text { Fee/Rec } \\
\text { Fishing }\end{array}$ & Process & $\begin{array}{c}\text { Retail Rest. } \\
\text { \& Food } \\
\text { Store }\end{array}$ & $\begin{array}{c}\text { Other } \\
\text { Outlets }\end{array}$ \\
\hline AL & 0 & 2 & 93 & 1 & 4 \\
AR & 3 & 0 & 97 & 0 & 0 \\
CA & 14 & 3 & 0 & 65 & 18 \\
FL & 0 & 0 & 30 & 0 & 70 \\
KY & 0 & 73 & 0 & 1 & 26 \\
LA & 0 & 0 & 99 & 0 & 1 \\
MS & 0 & 0 & 98 & 0 & 2 \\
MO & 58 & 18 & 3 & 3 & 18 \\
NC & 0 & 0 & 96 & 1 & 3 \\
OK & 18 & 8 & 43 & 0 & 31 \\
SC & 4 & 2 & 92 & 1 & 1 \\
TN & N/A & 11 & N/A & 16 & 49 \\
TX & 1 & 9 & 39 & 39 & 12 \\
Other States & 3 & 49 & 8 & 17 & 23 \\
\hline TOTAL & 1 & 1 & 94 & 2 & 2 \\
\hline
\end{tabular}




\section{TILAPIA MARKET AND PRICE INFORMATION}

The American Tilapia Association (ATA, 1901 North Fort Meyer Drive, Ste. 700, Arlington, VA) publishes an annual report entitled Tilapia Situation and Outlook Report. The following information is summarized from the 1996 version of that reference.

Tilapia production in the U.S. in 1996 is estimated at 16,000,000 lbs up 300\% in the period 1992 to 1996. Most of this production occurs in the western states led by California with a production of 6,200,000 lbs in 1996. In terms of growth, however, the largest increase was achieved in the north central region of the country where production moved from 1,850,000 lbs in 1995 to $2,600,000 \mathrm{lbs}$ in 1996. Projected national production in 1997 is $17,000,000 \mathrm{lbs}$ for a $6 \%$ gain over the 1996 figure.

Sixty percent of the national production is in the form of intensive culture. Many farms, particularly in California, Idaho and Oregon, are using geothermal water to control temperatures in their facilities. Table 6 presents the regional distribution of tilapia production in the continental U.S. for 1996.

Table 6. Continental U.S. Tilapia Production (in 1000 lbs live weight)

\begin{tabular}{|l|c|c|c|c|}
\hline \multicolumn{1}{|c|}{ Region } & 1994 & 1995 & 1996 & 1997 \\
\hline North Central & 1,400 & 1,850 & 2,600 & 2,675 \\
Northeast & 450 & 985 & 995 & 920 \\
South & 3,125 & 400 & 3,750 & 3,725 \\
West & 7,705 & 7,900 & 8,470 & 9,230 \\
\hline Total & 12,980 & 15,075 & 15,965 & 16,935 \\
\hline
\end{tabular}

Prices for tilapia have historically been higher $(\$ 0.25$ to $\$ 0.50$ per lb) in the western U.S. A substantial increase in production capacity in the past few years, however, has reduced prices to a level comparable to the east coast. Most of the production is sold into the live market in cities with large Asian populations such as Los Angeles, San Francisco and Seattle. Table 7 provides a summary of prices for 1996. 
Table 7. Average Tilapia Prices per lb - 1996

\begin{tabular}{|l|c|c|c|}
\hline & FOB Farm & Wholesale & Retail \\
\hline Live & $1.25-2.20$ & $1.60-2.40$ & $2.99-5.99$ \\
Whole Fresh & $1.05-1.60$ & $1.20-2.00$ & $1.99-3.49$ \\
Frozen Fillet & & $2.50-3.00$ & $3.49-4.99$ \\
Fresh Fillet & & $3.35-3.75$ & $3.99-6.99$ \\
Large Producer & $3.40-3.75$ & $3.60-4.00$ & $4.00-6.00$ \\
Medium Producer & $3.60-4.00$ & $3.80-4.20$ & $4.50-6.00$ \\
Small Niche & $4.00-5.00$ & & $5.00-8.00$ \\
\hline
\end{tabular}

\section{REFERENCES}

Economic Research Service, March 1998. "Aquaculture Outlook" URL: http://usda.mannlib.cornell.edu/reports/erssor/livestock/ldp-aqs/1998/aquaculture_outlook - 03.05 .98

National Agricultural Statistics Service, Feb. 1998. "Catfish Production" URL: http://usda.mannlib.cornell.edu/reports/nassr/other/pcf-bbc/1998/catfish_production_02.0 3.98

American Tilapia Association, 1996. "Tilapia Situation and Outlook Report," ATA, 1901 North Fort Meyer Dr., Ste 700, Arlington, VA. 
SECTION 2 - WATER QUALITY ISSUES IN AQUACULTURE 


\section{Section 2 \\ WATER QUALITY ISSUE IN AQUACULTURE}

\section{INTRODUCTION}

The information contained in this section was summarized from the Northeastern Regional Aquaculture Center Fact Sheet No. 170-1993 "An Introduction to Water Chemistry in Freshwater Aquaculture", 1993.

Some of the water quality factors that can affect growth of an aquaculture species are 1) temperature, 2) dissolved oxygen, 3) nitrogenous wastes, 4) $\mathrm{pH}, 5$ ) alkalinity, 6) hardness, 7) carbon dioxide, 8) salinity, 9) chlorine, and 10) hydrogen sulfide. Careful measurement and management of some/all of these factors is important for fish survival. A brief explanation of each factor and how to test for each one is listed below.

\section{TEMPERATURE}

Temperature has an influence on all biological and chemical process in an aquaculture operation. Each species has its own optimum temperature where it grows best. Growth rate is reduced when the temperature is above or below the optimum point and mortality can occur at extreme conditions.

\section{DISSOLVED OXYGEN}

The minimal safe level of dissolved oxygen is dependent on the temperature and to a certain extent the species. Throughout a 24 hour period the dissolved oxygen level of a pond can change dramatically. The lowest levels of dissolved oxygen generally occur just before dawn and the highest levels occur in the late afternoon. Warm water fish can tolerate lower levels of dissolved oxygen better than cold water fish. The level should be maintained above $3.0 \mathrm{ppm}$ or $5.0 \mathrm{ppm}$ for warm water and cold water fish respectively.

\section{NITROGENOUS WASTES}

Most fish excrete ammonia as their principle nitrogenous waste. The temperature and $\mathrm{pH}$ causes the proportion of total ammonia-nitrogen (TAN) (ionized \& un-ionized) to vary. The amount of TAN in the toxic un-ionized form increases with increasing $\mathrm{pH}$ and temperature. Ammonia is removed by bacteria that initially converts it into nitrite and subsequently into nitrate. High levels 
of nitrite causes "Brown Blood" disease and is toxic to fish. When concentrations are $0.5 \mathrm{ppm}$ or higher it can reduce growth and adversely affect the fish. Fish can tolerate nitrate to several hundred ppm.

pH

Fish grow best when the $\mathrm{pH}$ of water is between 6 - 9. Mortalities can occur at levels below 4.5 and higher than 10 . The lowest levels of $\mathrm{pH}$ are usually associated with the lowest levels of dissolved oxygen. High $\mathrm{pH}$ usually coincides with the high levels of dissolved oxygen.

\section{ALKALINITY}

Alkalinity is the buffering capacity of water or its ability to absorb acids and/or bases and is expressed as ppm calcium carbonate. Alkalinity is a measurement of carbonate and bicarbonate ions dissolved in the water. The $\mathrm{pH}$ shift due to photosynthetic activity is reduced in ponds with higher alkalinity. A suitable range is 20 to $300 \mathrm{ppm}$.

\section{HARDNESS}

While alkalinity measures carbonate and bicarbonates ions (negative), hardness measures the positive ions (calcium and magnesium). To some species, hardness of the water can be important. The hardness should be above $50 \mathrm{ppm}$.

\section{CARBON DIOXIDE}

Usually carbon dioxide problems can occur when using groundwater, high density fish transport and recirculating systems. Some solutions to keep carbon dioxide within acceptable levels are aeration, oxygenation, or buffering the water.

\section{SALINITY}

Salinity is the total concentration of all ions in the water. Salinity influences the concentration of un-ionized ammonia. Fish species exhibit a range in salinity tolerance. During the planning stage salinity should be checked to see if the water is appropriate for the culture of the species planned. 


\section{CHLORINE}

Typically municipal water supplies are treated with chlorine at $1.0 \mathrm{ppm}$. If municipal water is used, the residual chlorine must be removed. Even levels of chlorine as high as $0.02 \mathrm{ppm}$ are stressful to fish.

\section{HYDROGEN SULFIDE}

Hydrogen sulfide can be released when ponds with oxygen-poor bottoms are seined or disturbed. Hydrogen sulfide has a rotten egg smell and can be extremely toxic to fish. Hydrogen sulfide can also be present in groundwater.

How often should water quality be monitored? That question depends on several parameters. Is it going to be a high or low intensity culture? Is there going to be a high density of fish grown? The higher the intensity and more dense the culture, the more frequently the parameters should be checked. Table 1 contains the test procedures and preferred ranges for the water quality factors listed above.

Table 1. Water Quality Factors, Commonly Used Monitoring Procedures, and Preferred Ranges for Fish Culture

Water Quality Factor

Temperature

Dissolved Oxygen

Total Ammonia-Nitrogen (ionized and un-ionized)

Nitrite

$\mathrm{pH}$

Alkalinity

Hardness

Carbon dioxide

Salinity

Chlorine

Hydrogen Sulfide

\section{Test Procedure}

Thermometer, Telethermister

Titrimetric (Modified Winkler)

Polarographic meter, Calorimetric kits

Calorimetric kits

(Nesslerization or Salicylate), Ion specific probes

Calorimetric kits (Diazotization)

Ion Specific probes

Calorimetric kits, Electronic meter

Titrimetric with $\mathrm{pH}$ meter

Titrimetric with chemical indicator

Titrimetric kit

Titrimetric

Conductivity meter, Reflactometer Titrimetric

Calorimetric kit

Calorimetric kit

\section{Preferred Ranges for Fish Culture} species dependent

>4-5 ppm for most species

$\mathrm{NH}_{3}<0.02$

$<1$ ppm; 0.1 ppm in soft water

6-8

50-300 ppm calcium carbonate

$>50 \mathrm{ppm}$, preferably $>100 \mathrm{ppm}$ calcium carbonate

$<10 \mathrm{ppm}$

species dependent typically $<0.5-1.0 \mathrm{ppt}$ (For freshwater fish)

$<0.02 \mathrm{ppm}$

No detectable level 


\section{REFERENCE}

Buttner, Joseph K.; Soderberg, Richard W.; and Terlizzi, Daniel E. 1993. "An Introduction to Water Chemistry in Freshwater Aquaculture," Northeastern Regional Aquaculture Center Fact Sheet No. 170-1993. Northeastern Regional Aquaculture Center, University of Massachusetts, Darmouth, North Darmouth, Massachuesetts. 
SECTION 3 - CULTURE INFORMATION 


\section{Section 3 \\ CULTURE INFORMATION}

\section{TILAPIA}

This information was summarized from the following publications Southern Regional Aquaculture Center Publication No. 280, “Pond Culture of Tilapia", 1989, Southern Regional Aquaculture Center Publication No. 282, "Tank Culture of Tilapia", 1989 and "Introduction to Tilapia Culture", 1996, Auburn University.

Before you start a tilapia operation you must first determine which species, if any, can be legally cultured in your state. Tilapia are disease-resistant, reproduce easily, eat a wide variety of foods and tolerate poor water quality with low dissolved oxygen levels. An increasingly important criteria for selecting a species in the northern latitudes is cold tolerance. Tilapia nilotica, T. aurea, and hybrids between these species or strains are the most appropriate species of tilapia for tank culture in the US. T. aurea grow at the slowest rate, but this species has the greatest cold tolerance. This may allow it to have the highest growth rate in temperate regions at temperatures below optimum.

The optimum temperature range for growth of tilapia is between 77 to $86^{\circ} \mathrm{F}$ depending on the species. The low temperature tolerance is also species related and ranges from 46 to $55^{\circ} \mathrm{F}$. At temperatures lower than optimum, growth can be significantly diminished and if temperatures are too low death can occur.

Tilapia grow well at high densities in the confinement of tanks when good water quality is maintained. Tanks allow the fish culutrist to easily manage stocks and to exert a relatively high degree of environmental control over water quality parameters that can be adjusted for maximum production.

Geographic range for culturing tilapia in tanks is dependent on water temperature. The optimum range is 82 to $86^{\circ} \mathrm{F}$. Death can occur below $50^{\circ} \mathrm{F}$. Flow-through systems are only practical for year-round culture in temperate regions if geothermal water is available. Indoor recirculating systems are more appropriate for year-round culture, for the buildings can be insulated which will conserve heat and the heated water is saved through recycling.

\section{Flow-Through Systems}

The most durable tank materials are concrete and fiberglass and they should be non-toxic and non-corrosive. The most common tank shapes are circular and rectangle with the rectangle ones being long and narrow. Circular tanks are the most popular, for they usually tend to be self-cleaning. Rectangular tanks come in various dimensions and size and for proper operation the length to width to depth ratio should be 30:3:1 for a good flow pattern. 
Another important aspect of tank culture is the drain design. For effective removal of waste a center drain is best for circular tanks. The rate of water exchange can determine the aeration requirements. Aeration may not be required if the water is exchanged rapidly ( 1 to 4 times per hour). To support the oxygen requirement of 100 pounds of tilapia a flow rate of 6 to 12 gallons/minute is needed. Flow-through systems should be setup to take advantage of gravity fed water supplies. Aeration requirements can be estimated by using the aerator ratings and oxygen $\left(\mathrm{O}^{2}\right)$ consumption rates of tilapia, which consume $4.5 \mathrm{grams} \mathrm{O}^{2} / 100$ pounds of fish/hour while resting and several times more oxygen while they are feeding and active.

\section{Recirculating Systems}

In recirculating systems 90 to 99 percent of the water is recycled. The main components for a recirculating system are a clarifier (settling tank) and a biofilter. The clarifier is used to remove solid waste and the biofilter is used to remove toxic waste products (ammonia and nitrite) produced by the fish.

There are many effective biofilters designs, but they all operate on the same principle of providing a large surface area for the attachment of vitrifying bacteria that transforms ammonia into nitrite, which in turn is converted to nitrate. The biofilter can be sized by balancing the ammonia production rates with the ammonia removal rates. The required surface area of a biofilter can be obtained by dividing the total ammonia production for the maximum standing crop by the ammonia removal rate. The volume of the filter can be determined by dividing the required biofilter surface area by the specific surface area $\left(\mathrm{ft}^{2} / \mathrm{ft}^{3}\right)$ of the media.

\section{Breeding}

Tanks are commonly used to breed tilapia. Fry can be captured with a dip net and transferred to a nursery unit. The fry that avoid capture will prey on subsequent spawns which will cause production to decline. When that happens the tank must be drained to remove the juvenile fish and begin a new spawning cycle. Net enclosures (hapas) are used to obtain more controlled breeding. The use of hapas means all fry can be removed at regular intervals and insure size uniformity, predation reduction, and eliminated the need to drain the tanks. Hapas are made from nylon netting with a 1/16-inch mesh.

The male and female broodfish are stocked at a ratio of two females for each male to begin breeding. This will produce a large quantity of fry. For optimum stocking density the range is from 0.5 to $1.0 \mathrm{fish} / \mathrm{ft}^{2}$. The recommended feeding rate is two percent of their body weight per day with a high quality feed. A few days after the fry begin to appear they should be removed. To accomplish the removal of fry, the broodfish should be concentrated to one side of the tank. A largemesh dip net is used to remove the broodfish. The fry are then captured with a fine-mesh dip net and transferred to a nursery tank. Each broodfish should then have its mouth checked to remove any fry, sac fry or eggs that it may be incubating. 


\section{Production Management}

During the production cycle, the stocking density should be decreased at regular intervals to reduce crowding and ensure adequate water quality. Table 1 shows the recommended stocking and feeding rates for different size groups of tilapia. Fry are fed continuously throughout the day with automatic feeders and given a complete diet of powered feed. Under ideal conditions the initial feeding rate can be as high as 20 percent of body weight. Fingerlings require continuous feeding also, but the feed size can be increased to various grades of crumbles. The feed is changed during the growout periods to floating pellets to allow for visual inspection of the feeding response. For adult fish the daily ration is divided into three to six feedings evenly spaced throughout the day. Feeding levels should be reduced if the feed is not consumed rapidly. Recommended protein levels for fry are 40 percent, fingerlings 32 to 36 percent and for larger fish 28 to 32 percent.

Table 1. Recommended Stocking and Feeding Rates for Different Size Groups of Tilapia in Tanks and Estimated Growth Rates

\begin{tabular}{|c|c|c|c|c|c|}
\hline $\begin{array}{c}\text { Stocking Rate } \\
\text { (number/m }\end{array}$ & $\begin{array}{c}\text { Weight } \\
\text { Initial }\end{array}$ & $\begin{array}{c}\text { (grams) } \\
\text { Final }\end{array}$ & $\begin{array}{c}\text { Growth Rate } \\
\text { (g/day) }\end{array}$ & $\begin{array}{c}\text { Growth Period } \\
\text { (days) }\end{array}$ & $\begin{array}{c}\text { Feeding Rate } \\
\text { (\%) }\end{array}$ \\
\hline 8,000 & 0.02 & $0.5-1$ & - & 30 & $20-15$ \\
3,200 & $0.5-1$ & 5 & - & 30 & $15-10$ \\
1,600 & 5 & 20 & 0.5 & 30 & $10-7$ \\
1,000 & 20 & 50 & 1.0 & 30 & $7-4$ \\
500 & 50 & 100 & 1.5 & 30 & $4-3.5$ \\
200 & 100 & 250 & 2.5 & 50 & $3.5-1.5$ \\
100 & 250 & 450 & 3.0 & 70 & $1.5-1.0$ \\
\hline
\end{tabular}

$1 \mathrm{~m}^{3}=35.3 \mathrm{ft}^{3}, 1 \mathrm{~g}=0.0353 \mathrm{oz}=0.00220 \mathrm{lbs}$.

The fry rearing stage has the highest mortality (about 20 percent) of the production cycle. This is mostly due to predation. As the fish become hardier no more than 2 percent of the fish are expected to die during the final growout. Total production levels range from three to six pounds/ $\mathrm{ft}^{3}$ of rearing space and 6 to 17 pounds/gallon/minute of flow. Flow-through systems generally obtain the highest production levels.

There are only a few species of tilapia cultured around the world today. The following summarizes five of the most popular cultured species.

\section{Oreochromis Aureus}

Oreochromis aureus are mouth brooders and the female can spawn three or more times a year with 500 to 1400 eggs produced per spawn. The optimum temperature for spawning is from 73 to $82^{\circ} \mathrm{F}$. The eggs will hatch within three to five days, and the female will guard them for an additional eight to 10 days after hatching. Fry will eat zooplankton and adults will eat zooplankton, phytoplankton, and graze on the bottom organisms. The adults will also eat manufactured food. They grow well when salinities are keep below 1.6 to $2.0 \%$. Their optimum growing temperature is between 77 to $86^{\circ} \mathrm{F}$ and their low temperature tolerance is 46 to $48^{\circ} \mathrm{F}$. 


\section{Oreochromis Mossambicus}

Oreochromis mossambicus are mouth brooders and the female can spawn six to 12 times a year with 350 to 800 eggs produced per spawn. The optimum temperature for spawning is between 73 to $82^{\circ} \mathrm{F}$. The eggs hatch after two to five days and the female guards them for an additional eight to 10 days after hatching. Fry will eat zooplankton and adults will eat zooplankton, phytoplankton, and graze on the bottom organisms. The adults will also eat manufactured food. They can spawn and grow well in full strength sea water. Their optimum growing temperature is between 77 to $86^{\circ} \mathrm{F}$ and can not tolerate temperatures below 50 to $53^{\circ} \mathrm{F}$.

\section{Oreochromis Niloticus}

Oreochromis niloticus are mouth brooders and the females can spawn on an average of three times a year with 250 to 2000 eggs being produced per spawn. The optimum temperature for spawning is between 77 to $84^{\circ} \mathrm{F}$. The eggs hatch within three to five days from laying and the female guards them for an additional eight to 10 days after hatching. Fry will eat zooplankton and adults will eat phytoplankton, zooplankton, insects and other bottom organisms, plus manufactured food. They can grow well in salinity up to $2.0 \%$. Their optimum growing temperature is 77 to $86^{\circ} \mathrm{F}$ and can not tolerate temperatures below $52^{\circ} \mathrm{F}$.

\section{Tilapia Rendalli}

Tilapia rendalli are substrate spawners and spawning can occur at seven-week intervals with 12,000 to 20,000 eggs being produced per year. The optimum temperature for spawning is 77 to $86^{\circ} \mathrm{F}$ and the eggs hatch within five days from laying. Fry will eat zooplankton, while the adults eat aquatic weeds, insects, algae and manufactured food. They can grow well in brackish water. Their optimum growing temperature is $82^{\circ} \mathrm{F}$ and can't tolerate temperatures below $55^{\circ} \mathrm{F}$.

\section{Tilapia Zilli}

Tilapia zilli are substrate spawners and the females can spawn about six times a year with 1,000 to 7,000 eggs produced per spawn. The optimum spawning temperature range is 72 to $79^{\circ} \mathrm{F}$ and the eggs will hatch within three to five days. Fry will eat zooplankton, while the adults eat phytoplankton, leaves, stems rooted aquatic vegetation, and manufactured food. They can grow well in full strength sea water. Their optimum growing temperature is $82^{\circ} \mathrm{F}$ and can't tolerate temperatures below $48^{\circ} \mathrm{F}$. 


\section{CHANNEL CATFISH}

This information was summarized from the following publications North Central Regional Extension Publication No. 444 "Pond Culture of Channel Catfish in the North Central Region", 1993 and Southern Regional Aquaculture Center Publication No. 18 "Channel Catfish Life History and Biology," 1988.

This is the principal warm water species grown in the Southeastern US and the most popular fish currently cultured in the US. They are mostly raised in ponds $1 / 2$ to 10 acres in size. In an existing pond, cage culture represents one way for those considering fish farming to try their hand at fish culture with a minimal cash investment.

When water temperatures are between 80 to $85^{\circ} \mathrm{F}$, optimal growth occurs. The high and low temperature limits are 45 to $95^{\circ} \mathrm{F}$. Channel catfish are known for their ability to withstand lower water quality conditions, but limits do exist. Table 2 shows the suggested safe limits for the water quality parameters for channel catfish.

With each $18^{\circ} \mathrm{F}$ change in temperature there is a doubling or halving of their metabolic rate. This means that within limits, their appetite increases with increasing water temperatures or decreases with decreasing water temp. Most farm-raised catfish are harvested at a weight of $11 / 4$ pounds at an age of about 18 months.

Table 2. Suggested safe limits for water quality parameters for Channel catfish

\begin{tabular}{|l|c|}
\hline \multicolumn{1}{|c|}{ Parameters } & Recommended Range \\
\hline Dissolved Oxygen & $4 \mathrm{ppm}$ or above \\
Alkalinity & $20-400 \mathrm{ppm}$ \\
Hardness & $20-400 \mathrm{ppm}$ \\
$\quad$ Ponds & $20-400 \mathrm{ppm}$ \\
Hatcheries & above $10-20 \mathrm{ppm}$ \\
$\mathrm{pH}$ & $6-9 \mathrm{ppm}$ \\
Un-ionized Ammonia & less than $0.05 \mathrm{ppm}$ \\
Nitrite & \\
Minimum Chloride & minimum $5: 1$ \\
Nitrite Ratio & $0 \mathrm{ppm}$ \\
Hydrogen Sulfide & less than $20 \mathrm{ppm}$ \\
Carbon Dioxide & \\
$\quad$ Depend on Oxygen Level &
\end{tabular}




\section{Brood Stock}

Channel catfish that have been domesticated through several generations are preferred over wild stock. Brood stock should be obtained in the fall prior to or at least two months before the spawning season starts. They should have robust bodies, be free of wounds and diseases, and not be larger than 6 - $8 \mathrm{lbs}$. Females weighing 3-4 lbs, will provide approximately 4,000 eggs/lb of body weight. Females over four lbs will produce approximately 3,000 eggs/lb.

During the winter months brood stock should be fed on sunny days when the air temperature is above $32^{\circ} \mathrm{F}$. Since food consumption is limited by temperature, you should feed between $1 / 2$ to one percent of the ponds total fish weight 2-3 times a week. The purpose of this is to maintain their weight, not increase it.

\section{Spawning}

Brood stock should be collected from their wintering ponds at least 6-8 weeks before spawning and taken to a common facility. Catfish spawn when the water temperature is between 75 to $85^{\circ} \mathrm{F}$ with $80^{\circ} \mathrm{F}$ being optimum. Channel catfish are cavity spawners and will spawn only in secluded, semi-dark areas. 


\section{PRAWNS}

This information was summarized from the following publications Southern Regional Aquaculture Center Publication No. 483, "Biology and Life History of Freshwater Prawns", 1996 and Southern Regional Aquaculture Center Publication No. 484, "Production of Freshwater Prawns in Pond", 1996.

Basic production techniques for Macrobrachium rosenbergii (Malaysian Prawn) were developed in the late $1950 \mathrm{~s}$ in Malaysia.

In order for growth to occur, freshwater prawns, like all crustaceans, have a hard outer skeleton or shell that must be shed regularly. Due to these periodic sheddings, growth occurs in distinct increments, rather than continuously. The process of shedding the shell is called "molting," and weight and size increase occur principally soon after each molt.

\section{Breeding}

At six months of age females generally are reproductively mature. Females who have just completed a premating or prenuptial molt are the only ones who can mate for mating can only occur between hard-shelled males and soft-shelled females. The size of the female is directly proportional to the number of eggs produced at each spawn and as long as the water temperature exceeds $70^{\circ} \mathrm{F}$, multiple spawns per female can occur annually.

\section{Larvae}

The larvae survive best in brackish water with salinities of 9 to 19 parts per thousand (ppt) and cannot survive in freshwater beyond approximately 48 hours. The larvae will undergo 11 molts, each representing a different stage of metamorphosis. The transformation requires 15 to 40 days from newly hatched larvae to postlarvae, depending on food quality and quantity, temperature, and a variety of other water quality variables. Optimum temperatures for growth are about 82 to $88^{\circ} \mathrm{C}$.

\section{Postlarvae}

Postlarvae resemble miniature adult prawns and weigh from 6 to $9 \mathrm{mg}(50,000$ to 76,000 per pound) and are about 0.3 to 0.4 inches long. At this point their behavior will change and become principally bottom dwellers. They can tolerate a range of salinities and will migrate to freshwater upon transformation. The diet for postlarvae includes larval and adult insects, algae, mollusks, worms, fish, and feces of fish and other animals. Prawns will become cannibalistic at high densities, or under conditions of food limitations. 
Adult

Adult males are larger than the females, and the sexes are easily distinguishable. The second walking legs or claws (chela) and the head region of males are larger than those of the females. There are three types of males which are distinguished by their external characteristics. The blueclaw (BC) are distinguished by their long spiny blue claw. There is also the orange claw (OC) and the strong orange claw (SOC). The transformation sequence for the males is from $\mathrm{OC}$ to SOC to $\mathrm{BC}$. The $\mathrm{BC}$ is the most successful at mating. He maintains a territory associated with a group of females ready for mating and protects them during the vulnerable period before and after molting.

\section{Stocking of Juveniles}

Juveniles is the stage between the postlarvae and adult. When transporting the juveniles to the growout pond they should be acclimated to the conditions of the pond to prevent temperature shock. Juveniles appear to be more susceptible to lower temperatures than adults and the pond water at stocking should be keep at least $68^{\circ} \mathrm{F}$. For a yield of larger prawns, lower stocking densities are essential, but will produce a lower total harvested poundage. The grow out period is dependent upon water temperature.

\section{Feeding}

Juveniles are able to obtain sufficient nutrition from the organisms present in the pond when initially stocked. When the average weight of the prawn is $5.0 \mathrm{~g}(0.18 \mathrm{oz})$ or greater, feeding should be started. The feeding rate should be based on the mean weight of the population. Table 3 is an example for a semi-intensive pond grow out.

Table 3. Weight-Dependent Feeding Rates

\begin{tabular}{|c|c|}
\hline Mean Wet Weight (g) & $\begin{array}{l}\text { Daily Feeding Rate } \\
\text { (\% of Body Weight) }\end{array}$ \\
\hline$<5$ & 0 \\
5 to 15 & 7 \\
15 to 25 & 5 \\
$>25$ & 3 \\
\hline
\end{tabular}

If good water quality maintenance is practiced survival rate for the grow out season can range from 60 to 85 percent. Depending on initial stocking density a typical yield can range from 600 to 1,200 pounds per acre with individual weights from 35 to $45 \mathrm{~g}$ (1.2 to $1.6 \mathrm{oz}$.) 


\section{Water Quality Management}

Dissolved oxygen is important, and a good monitoring program is essential to achieve maximum yields. The dissolved oxygen should be checked in the bottom one foot of the pond, since prawns are bottom dwellers. The level of dissolved oxygen should not fall below three part per million (ppm). This can be stressful to prawns and at lower levels lethal. The prevention of thermal stratification is also important, but if a pond does not exceed the recommended depth and aeration is employed properly, thermal stratification is unlikely.

The levels of un-ionized ammonia should also be checked. When levels are higher than 0.1 $\mathrm{ppm}$ it can be detrimental to the prawns, therefore every effort to keep levels below $0.1 \mathrm{ppm}$ is recommend. Prawns have been raised in ponds with $\mathrm{pH}$ levels from 6.0 to 10.5 and showed no adverse affects, the recommend range is from 6.5 to 9.5 .

\section{REFERENCES}

Rakocy, James E. and Andrew S. McGinty. 1989. "Pond Culture of Tilapia," Southern Regional Aquaculture Center Publication No. 280. Texas Agricultural Extension Service, Texas A\&M University System, College Station, Texas.

Rakocy, James E. 1989. “Tank Culture of Tilapia," Southern Regional Aquaculture Center Publication No. 282. Texas Agricultural Extension Service, Texas A\&M University System, College Station, Texas.

Bocek, Alex, Editor. 1996. "Introduction to Tilapia Culture". International Center for Aquaculture and Aquatic Environments, Auburn University, Alabama.

Wellborn, Thomas L. 1988. "Channel Catfish - Life History and Biology," Southern Regional Aquaculture Center Publication No. 18. Texas Agricultural Extension Service, Texas A\&M University System, College Station, Texas.

Morris, J. E. 1993. "Pond Culture of Channel Catfish in the North Central Region," North Central Regional Extension Publication No. 444. Department of Animal Ecology, Iowa State University, Ames, IA.

D'Abramo, Louis R. and Martin W. Bronson. 1996. "Biology and Life History of Freshwater Prawns," Southern Regional Aquaculture Center Publication No. 483. Texas Agricultural Extension Service, Texas A\&M University System, College Station, Texas.

D'Abramo, Louis R. And Martin W. Bronson. 1996. "Production of Freshwater Prawns in Ponds", Southern Regional Aquaculture Center Publication No. 484. Texas Agricultural Extension Service, Texas A\&M University System, College Station, Texas. 
SECTION 4 - POND AND RACEWAY HEAT LOSS CALCULATIONS 


\section{Section 4 \\ POND AND RACEWAY HEAT LOSS CALCULATIONS}

\section{INTRODUCTION}

One of the most common areas of interest in geothermal direct use is that of aquaculture. For those involved with the initial planning of such a project, one of the first questions to be addressed relates to project size. In most geothermal applications, the maximum pond area that can be developed is restricted by the maximum heat available from the resource. It is the purpose of this chapter to present a brief introduction to the subject of heat loss from ponds (or pools) so that developers can make an informed evaluation of geothermal resources for this purpose.

\section{TEMPERATURE REQUIREMENTS FOR SELECTED SPECIES}

In order to determine the heat loss of the ponds, it is necessary to first select the temperature at which the water must be maintained. Table 1 provides a summary of appropriate temperatures for selected species. In addition, growth periods for cultures at optimum temperatures are shown in the last column.

\section{HEAT EXCHANGE PROCESSES}

A non-covered body of water, exposed to the elements, exchanges heat with the atmosphere by way of four mechanisms: (a) evaporation, (b) convection, (c) radiation, and (d) conduction. Each of these is influenced by different parameters that are discussed separately in the following paragraphs.

\section{Evaporative Loss}

Evaporation is generally the largest component of the total heat loss from the pond. Considering evaportion, the loss of volume generally comes to mind rather than the loss of heat. However, in order to boil water (and hence cause evaporation) heat must be added. The quantity of heat required to evaporate one pound of water varies with temperature and pressure, but under normal atmospheric conditions the value is approxmately 1,000 British thermal units (Btu). When water is evaporated from the surface of the pond, the heat is taken from the remaining water. As a result, as each pound of water evaporates from the surface, approxiately $1,000 \mathrm{Btu}$ are lost with escaping vapor.

Table 1. Temperature Requirements and Growth Periods for Selected Aquaculture Species"

\begin{tabular}{|c|c|c|c|}
\hline Species & $\begin{array}{c}\text { Tolerable } \\
\text { Extremes }\left({ }^{\circ} \mathrm{F}\right)\end{array}$ & $\begin{array}{l}\text { Optimum } \\
\text { Growth }\left({ }^{\circ} \mathrm{F}\right)\end{array}$ & $\begin{array}{c}\text { Growth Period } \\
\text { to Market Size (mos) }\end{array}$ \\
\hline Oysters & 32 to 97 typ & 76 to 78 typ & 24 \\
\hline Lobsters & 32 to 88 & 72 to 75 & 24 \\
\hline \multicolumn{4}{|l|}{ Penaeid Shrimp } \\
\hline Kuruma & 40 to ? & 77 to 87 & 6 to 8 typ \\
\hline Pink & 52 to 104 & 75 to 85 & 6 to 8 \\
\hline Salmon (Pacific) & 40 to 77 & 59 & 6 to 12 \\
\hline Freshwater Prawns & 75 to 90 & 83 to 87 & 6 to 12 \\
\hline Catfish & 35 to 95 & 82 to 87 & 6 \\
\hline Eels & 32 to 97 & 73 to 86 & 12 to 24 \\
\hline Tilapia & 47 to 106 & 72 to 86 & - \\
\hline Carp & 40 to 100 & 68 to 90 & - \\
\hline Trout & 32 to 89 & 63 & 6 to 8 \\
\hline Yellow Perch & 32 to 86 & 72 to 82 & 10 \\
\hline Striped Bass & $?$ to 86 & 61 to 66 & 6 to 8 \\
\hline
\end{tabular}

a. Behrends, 1978 
Losses can occur by evaporation even when the water temperature is at or below the surrounding air temperature.

The rate at which evaporation occurs is a function of air velocity and the pressure difference between the pond water and the water vapor in the air (vapor pressure difference). As the temperature of the pond water is increased or the relative humidity of the air is decreased, evaporation rate increases. The equation that describes the rate of evaporation is (ASHRAE, 1995). where

$$
W p=(0.097+0.038 v) \times(P w-P a) \times A
$$

$$
\begin{aligned}
& \mathrm{Wp}=\text { rate of evaporation }(\mathrm{lbm} / \mathrm{h}) \\
& \mathrm{A}=\text { pond surface area }\left(\mathrm{ft}^{2}\right) \\
& \mathrm{v}=\text { air velocity, }(\mathrm{mph}) \\
& \mathrm{Pw}=\begin{array}{l}
\text { saturation vapor pressure of the pond water } \\
\text { (psia) }
\end{array} \\
& \mathrm{Pa}=\text { saturation pressure at the air dew point (psia) }
\end{aligned}
$$

For enclosed ponds or indoor swimming pools, this equation can be reduced to (ASHRAE, 1995).

$$
\mathrm{Wp}=0.204 \times \mathrm{A} \times(\mathrm{Pw}-\mathrm{Pa})
$$

where

$$
\begin{aligned}
& \mathrm{Wp}=\text { rate of evaporation }(\mathrm{lbm} / \mathrm{h}) \\
& \mathrm{A}=\text { pond area }\left(\mathrm{ft}^{2}\right) \\
& \mathrm{Pw}=\text { saturation pressure of the pond water (psia) } \\
& \mathrm{Pa}=\text { saturation pressure at air dew point (psia) }
\end{aligned}
$$

Following are some common values for $\mathrm{PW}$ and $\mathrm{Pa}$ :

$$
\text { For Pw: } \begin{array}{r}
@ 60^{\circ} \mathrm{F} \text { water, Pw }=0.256 \text { psia } \\
@ 70^{\circ} \mathrm{F} \text { water, Pw }=0.363 \text { psia } \\
@ 80^{\circ} \mathrm{F} \text { water, Pw }=0.507 \text { psia } \\
@ 90^{\circ} \mathrm{F} \text { water, Pw }=0.698 \text { psia }
\end{array}
$$

For Pa: For outdoór locations with a design dry bulb air temperature below $30^{\circ} \mathrm{F}, \mathrm{Pa}$ can be taken as 0.074 psia.

For indoor locations with a design of approximately $75^{\circ} \mathrm{F}$ and $50 \%$ relative humidity, $\mathrm{Pa}$ can be taken as 0.211 psia.
For example, assume a pond with a surface area of 500 $\mathrm{ft}^{2}$ (10 ft $\times 50 \mathrm{ft}$ ) located outside in an area with design temperature of $15^{\circ} \mathrm{F}$. Wind velocity is $5 \mathrm{mph}$ and pond water is to be $80^{\circ} \mathrm{F}$.

$$
\begin{aligned}
W p= & (0.097+(0.038 \times 5)) \times(.507-.074) \times 500 \\
& =62.1 \mathrm{lb} / \mathrm{hr}
\end{aligned}
$$

To obtain the heat loss $\left(\mathrm{q}_{\mathrm{Ev}}\right)$ in $\mathrm{Btu} / \mathrm{h}$, simply multiply the $\mathrm{lbm} / \mathrm{h}$ loss by the value of $1,050 \mathrm{Btu} / \mathrm{lbm}$.

$$
\begin{aligned}
& \mathrm{q}_{\mathrm{EV}}=62.1 \mathrm{lb} / \mathrm{h} \times 1,050 \mathrm{Btu} / \mathrm{lb} \\
& \mathrm{q}_{\mathrm{EV}}=65,200 \mathrm{Btu} / \mathrm{h}
\end{aligned}
$$

This is the peak or design heat loss. It is important to note that the example values given above are for the design (worst) case. At higher outdoor air temperatures and different relative humidities, this value would be less. As mentioned earlier, the rate of evaporation loss is influenced by the vapor pressure difference between the pond water and the water vapor in the air. Reduced water temperature would reduce the vapor pressure differences and hence, the rate of evaporation.

Wind speed over the surface of the water has a very substantial impact upon both evaporative and convective heat losses from ponds. When calculating the design heat loss for ponds, it is not necessary to use unrealistically high wind speeds. In general, the coldest outdoor temperatures are not accompanied by high wind speed conditions.

In addition, sustained high wind conditions are generally not experienced for extended periods of time. This, coupled with the high thermal mass of the water, allows the pond or pool to sustain brief high wind periods without significant water temperature drop.

Mean wind speeds which appear in Chapter 1 of the Department of Defense publication Engineering Weather Data (AFM 88-29)(1978) are appropriate values for these calculations.

Pond surface area can be influenced by surface disturbances due to waves or the use of splash-type aeration devices. The calculation presented above are 
based upon a calm water surface. If surface disturbances exist, the pond surface area (" $A$ " in the above equation) should be increased to reflect the departure from the calm water condition.

\section{Convective Loss}

The next major mechanism of loss from the pond surface is that of convection. This is the mode associated with the heat loss caused by cold air passing

over the pond surface. The two most important influences on the magnitude of convective heat loss are wind velocity and temperature difference between the pond surface and the air. This is evidenced in (Wolf, 1983):

$$
q_{C v}=(0.198 v) \times A \times(T w-T a)
$$

where

$$
\begin{aligned}
& \mathrm{q}_{\mathrm{cv}}=\text { convection heat loss }(\mathrm{Btu} / \mathrm{h}) \\
& \mathrm{v}=\text { air velocity }(\mathrm{mph}) \\
& \mathrm{A}=\text { pond area }\left(\mathrm{ft}^{2}\right) \\
& \mathrm{T} \mathrm{w}=\text { water temperature }\left({ }^{\circ} \mathrm{F}\right) \\
& \mathrm{Ta}=\text { air temperature }\left({ }^{\circ} \mathrm{F}\right)
\end{aligned}
$$

The shape of the pond and the direction of the prevailing wind influences the magnitude of the convective heat loss. The method used here is appropriate for pond dimensions of up to approximately $100 \mathrm{ft}$. For very large ponds, convective losses would be up to $25 \%$ less than the figure which result from this method. undated):

For an indoor pool, this equation would be (Lauer,

$$
\mathrm{q}_{\mathrm{cv}}=0.38(\mathrm{Tw}-\mathrm{Ta})^{0.25} \times \mathrm{A} \times(\mathrm{Tw}-\mathrm{Ta})
$$

Using the example from above $\left(15^{\circ} \mathrm{F}\right.$ design temperature, $80^{\circ} \mathrm{F}$ water and $5 \mathrm{mph}$ wind), the following convective heat loss can be calculated:

$$
\begin{aligned}
& \mathrm{q}_{\mathrm{CV}}=(0.198 \times 5 \mathrm{ft} / \mathrm{s}) \times 500 \mathrm{ft}^{2} \times\left(80^{\circ}-15^{\circ}\right) \\
& \mathrm{q}_{\mathrm{CV}}=32,200 \mathrm{Btu} / \mathrm{h}
\end{aligned}
$$

\section{Radiant Loss}

Radiant heat loss, the third largest component of the total heat loss is dependent primarily on the temperature difference between the pond surface temperature and the surrounding air temperature. Under normal circumstances, radiant heat exchange is assumed to occur between solid bodies with little or no gain to the air in between the bodies. However, because of the evaporative losses near the pond surface, the air tends to contain a large quantity of water vapor. When this is the case, the pond surface radiates to the water vapor in the air, which is assumed to be at the temperature of the air itself. The equation describing this process is (Stoever, 1941):

$$
\begin{aligned}
\mathrm{q}_{\mathrm{RD}}= & 0.174 \times 10^{-8} \times 0.93\left[(460+\mathrm{Tw})^{4}\right. \\
& \left.-(460+\mathrm{Ta})^{4}\right] \times \mathrm{A}
\end{aligned}
$$

where

$$
\begin{aligned}
& \mathrm{q}_{\mathrm{RD}}=\text { radiant heat loss }(\mathrm{Btu} / \mathrm{h}) \\
& \mathrm{Tw}=\text { pond water temperature }\left({ }^{\circ} \mathrm{F}\right) \\
& \mathrm{Ta}=\text { air temperature }\left({ }^{\circ} \mathrm{F}\right) \\
& \mathrm{A}=\text { pond surface area }\left(\mathrm{ft}^{2}\right)
\end{aligned}
$$

Again referring to the above example $\left(15^{\circ} \mathrm{F}\right.$ design temperature, $80^{\circ} \mathrm{F}$ pond temperature), the following radiant heat loss is calculated:

$$
\begin{aligned}
\mathrm{q}_{\mathrm{RD}}= & 0.174 \times 10^{-8} \times 0.93\left[\left(460+80^{\circ} \mathrm{F}\right)^{4}\right. \\
& \left.-(460+15)^{4}\right] \times 500 \\
\mathrm{q}_{\mathrm{RD}}= & 27,600 \mathrm{Btu} / \mathrm{h}
\end{aligned}
$$

\section{Conductive Loss}

The final mode of heat loss is that of conduction. This is the loss associated with the walls of the pond. Of the four losses, conduction is by far the smallest and in many calculations is simply omitted. The following method (ASHRAE, 1985) is valid for a pond depth of 3 to $5 \mathrm{ft}$.

$$
\mathrm{q}_{\mathrm{cd}}=\{[(\mathrm{L}+\mathrm{W}) 2]+(\mathrm{L} \quad \mathrm{W} \quad 0.02)\}[(\mathrm{Tw}-(\mathrm{Ta}+15)]
$$


where

$$
\begin{aligned}
& \mathrm{q}_{\mathrm{CD}}=\text { conductive heat loss }(\mathrm{Btu} / \mathrm{h}) \\
& \mathrm{L}=\text { length of pond }(\mathrm{ft}) \\
& \mathrm{W}=\text { width of pond }(\mathrm{ft}) \\
& \mathrm{Tw}=\text { design water temperature }\left({ }^{\circ} \mathrm{F}\right) \\
& \mathrm{Ta}=\text { design outside air temperature }\left({ }^{\circ} \mathrm{F}\right)
\end{aligned}
$$

This calculation assumes the use of lined pond construction. That is, there is no significant leakage of water from the walls or floor of the pond.

Using the previous example, the following conductive heat loss is calculated: 15)]

$q_{C D}=\{[(10+50) \times 2]+(10 \times 50 \times 0.02)\}[80-(15+$

\begin{tabular}{|c|c|c|}
\hline Heat Loss Method & Loss $(\mathrm{Btu} / \mathrm{h})$ & Amount (\%) \\
\hline Evaporation & 65,200 & 50 \\
\hline Convection & 32,200 & 24 \\
\hline Radiation & 27,600 & 21 \\
\hline Conduction & 6,500 & 5 \\
\hline TOTAL & $\overline{131,500}$ & $\overline{100}$ \\
\hline
\end{tabular}

$$
\mathrm{q}_{\mathrm{CD}}=6,500 \mathrm{Btw} / \mathrm{h}
$$

Table 2 summarizes the results of the calculations performed for the example $500 \mathrm{ft}^{2}$ pond.

Table 2. Summary of Example Heat Loss

These losses are the peak or maximum heat loss. At any given time during the year, other than the design case, the heat loss would be less than this value. The annual heating requirement cannot be determined from simply multiplying the peak heating requirement by 8760 $\mathrm{h} / \mathrm{y}$. Because of the need for consideration of varying temperature, wind, humidity, and solar heat gain, methods for calculating the annual heating requirement are beyond the scope of this chapter.

\section{SURFACE COVER}

Heat losses from the pond surface are most heavily influenced by wind velocity and the temperature difference between the pond and the surrounding air. Any method that can be employed to reduce these values can substantially reduce heating requirements.

For outdoor pools, a floating cover is an excellent

\begin{tabular}{|c|c|c|}
\hline Heat Loss Method & Loss (Btu/h) & Amount (\%) \\
\hline Evaporation & 0 & 0 \\
\hline Convection & 5,200 & 35 \\
\hline Radiation & 3,200 & 22 \\
\hline Conduction & 6,500 & 43 \\
\hline TOTAL & $\overline{14,900}$ & $\overline{100}$ \\
\hline
\end{tabular}
example. The use of a 0.5 in. floating foam cover (on the pool surface) would reduce the peak heat loss for the example pool to the values shown in Table 3.

Table 3. Summary of Example Heat Loss Using Pool Cover

This peak load is only approximately $11 \%$ of the originally calculated heat loss. This is, in large measure, a result of the elimination of evaporation loss that is provided by a floating type cover. Unfortunately, a floating cover is generally not considered practical for commercial aquaculture applications.

\section{POND ENCLOSURE}

A pond enclosure is another (though much more expensive) option for reducing heat loss. The advantages provided by an enclosure depend to a large extent upon the construction techniques employed (covering material, degree of enclosure, presence, or absence of ventilation. The variety of construction methods and materials available are too numerous to cover here. The basic advantages of an enclosure are: (a) reduced air velocity, (b) reduced temperature difference between the pond and surrounding air, and (c) reduced vapor pressure difference between the pond water and air (increased relative humidity). These effects reduce the losses associated with evaporation, convection and radiation.

Assuming an enclosure is placed over our example pond, reducing air velocity to the 10 to $30 \mathrm{ft} / \mathrm{min}$ range, increasing humidity to $90 \%$ and air temperature to $48^{\circ} \mathrm{F}$ 
(half way between outside air and pond water temperature), pond heat loss would be reduced to the values shown in Table 4.

Table 4. Summary of Example Heat Loss Using Pond Enclosure

\begin{tabular}{lccc} 
Heat Loss Method & & Loss (Btu/h) & Amount (\%) \\
Evaporation & & 35,200 & 47 \\
Convection & & 14,500 & 19 \\
Radiation & 18,200 & 25 \\
Conduction & & 6,500 & $\frac{9}{100}$ \\
\multicolumn{1}{c}{ TOTAL } & 74,400 &
\end{tabular}
example.

This value amounts to $57 \%$ of the original

It is often erroneously believed that the use of a pond enclosure will allow the air within to become saturated and thus, eliminate evaporative loss from the pond surface. This is not the case in most applications. For greenhouse-type enclosures (the most common), the inside surface temperature of the roof and walls is well below the dew point of the air during the winter. This results in substantial condensation occurring on these surfaces. As a result, moisture is continuously removed from the air allowing more to be absorbed (through evaporation) from the pond surface.

For conventional constructed buildings, ventilation air is normally supplied to reduce humidity in the space to a point which will protect the structure from moisture damage. Under these conditions of course, evaporation continues to occur and an additional heating load is imposed by the requirement to heat the ventilation air. This topic is covered in detail in Chapter 4 of the 1995 ASHRAE Handbook of Applications.

\section{THERMAL MASS}

One final method for reducing peak heating requirements for pond or pool heating lies in the use of the large thermal mass supplied by the water itself. Water is an excellent heat storage medium. Assuming the example pond is $5 \mathrm{ft}$ deep and $500 \mathrm{ft}^{2}$ in area, the total volume contained would be $2,500 \mathrm{ft}^{3}$. At 7.49 $\mathrm{gal} / \mathrm{ft}^{3}$, this results in 18,725 gal or $156,000 \mathrm{lbm}$ of water at $8.33 \mathrm{lbm} / \mathrm{gal}$. Be-cause $1 \mathrm{lb}$ of water gives up one Btu for each degree it is cooled, this means that our example pond that contains $156,000 \mathrm{lbm}$ of water could provide $156,000 \mathrm{Btu}$ of offset heating requirements if it were allowed to cool $1^{\circ} \mathrm{F}$. This stored heating capacity can be used to reduce the peak heating requirement on the heating system. Using the originally calculated peak heating requirement of $131,500 \mathrm{Btu} / \mathrm{h}$, an example of thermal storage use follows. Assume that the peak heating requirement occurs over an 8-hour period after which, because of air temperature increase and solar gain, the heating load is reduced. Further, assume that the heating system is designed to supply only $80 \%$ of the peak requirement. What will happen to the pond temperature?

First, calculate the total heat required for the 8-hr period.

$$
8 \mathrm{~h} \times 131,500 \mathrm{Btu} / \mathrm{h}=1,052,000 \mathrm{Btu}
$$

Second, calculate the heat that the system can supply based on its $80 \%$ capacity.

$$
8 \mathrm{~h} \times(0.80 \times 131,500 \mathrm{Btu} / \mathrm{h})=842,000 \mathrm{Btu}
$$

Then, calculate the difference to be supplied by allowing the pond water to cool.

$$
1,052,000 \mathrm{Btu}-842,000 \mathrm{Btu}=210,400 \mathrm{Btu}
$$

Finally, calculate the drop in pond temperature caused by supplying the heat required.

$$
210,400 \mathrm{Btu} /\left(156,000 \mathrm{lbm} \times 1 \mathrm{Btu} / \mathrm{lbm}^{\circ} \mathrm{F}\right)=1.35^{\circ} \mathrm{F} .
$$

As a result, the pond will have cooled by $1.35^{\circ} \mathrm{F}$. The heating system would then bring the pond back up to the temperature during the day when higher temperatures and solar gain would reduce heating requirements.

An alternate way of looking at this is in terms of the selection of the ambient temperature to be used in the calculation of the pond losses. Use of the mean-duty temperature in-stead of the minimum-duty temperature would allow the design to incorporate the effect of the pond thermal mass on the heat loss. Use of an air temperature higher than the mean-duty value could be 
employed in very clear climates where solar heat gain can be assumed to contribute to pond heating during the day.

The degree to which thermal storage can be incorporated into the heating system design is a complex issue of environmental factors, pond characteristics, and the species being raised. Some species, such as prawns, are particularly sensitive to temperature fluctuations (Johnson, 1978).

\section{FLOW REQUIREMENTS}

The rate of flow required to meet the peak heating demand of a particular pond is a function of the temperature difference between the pond water and the resource temperature. The following equation can be used to determine the flow $(\mathrm{Q})$ requirement and is written:

$$
Q=q_{100} /[500 \times(T r-T w)]
$$

where

$$
\begin{aligned}
\mathrm{Q} & =\text { resource flow requirement (gpm) } \\
\mathrm{q}_{\mathrm{rot}} & =\text { total calculated pond heat loss } \\
& =\mathrm{q}_{\mathrm{EV}}+\mathrm{q}_{\mathrm{CV}}+\mathrm{q}_{\mathrm{RD}}+\mathrm{q}_{\mathrm{CD}} \\
\mathrm{TW} & =\text { pond temperature }\left({ }^{\circ} \mathrm{F}\right) \\
\mathrm{Tr} & =\text { resource temperature }\left({ }^{\circ} \mathrm{F}\right) \\
500 & =\text { constant }\left(\mathrm{Btu} / \mathrm{h} \text { gpm }{ }^{\circ} \mathrm{F}\right)
\end{aligned}
$$

Assuming that our example pond is to be heated with a resource temperature of $100^{\circ} \mathrm{F}$ :

$$
\begin{aligned}
& \mathrm{Q}=105,120 \mathrm{Btu} / \mathrm{h} /\left[500 \times\left(100^{\circ} \mathrm{F}-80^{\circ} \mathrm{F}\right)\right] \\
& Q=10.5 \mathrm{gpm}
\end{aligned}
$$

Again, the point is made that this is the peak requirement. The required flow at any other time would be a value $<10.5 \mathrm{gpm}$. This approach is valid for aquaculture projects and,resource temperatures up to levels that would prove harmful if supplied directly to the pond. Above this temperature (which varies according to species), the heating water would have to be mixed with cooler water to reduce its temperature. Two methods are possible for mixing. If a sufficient supply of cold water is available, the hot water could be mixed with the cold water before introduction in the pond. A second approach, which would apply in the absence of cold water, would be to recirculate pond water for mixing purposes. The recirculation could be combined with an aeration scheme to increase its beneficial effect. In both cases, the quantity of cold or recirculated water could be determined by the following formula:

$$
Q_{c}=\frac{Q_{h}\left(T_{h}-T_{m}\right)}{\left(T_{m}-T\right)}
$$

where

$Q_{c}=$ required cold flow rate (gpm)

$\mathrm{Q}_{\mathrm{h}}=$ hot water flow rate $(\mathrm{gpm})$

$\mathrm{T}_{\mathrm{h}}=$ temperature of hot water $\left({ }^{\circ} \mathrm{F}\right)$

$T_{c}=$ temperature of cold water $\left({ }^{\circ} \mathrm{F}\right)$

$\mathrm{T}_{\mathrm{m}}=$ temperature of desired mixed water $\left({ }^{\circ} \mathrm{F}\right)$

The above methods are presented to provide interested individuals with an introduction to the subject of heat losses from ponds. The equations provided are simplifications of very complex relationships and should be employed only for initial calculations. In addition, losses that can occur from various aeration schemes and other activities have not been addressed. It is strongly recommended that a competent engineer be enlisted for final design purposes.

\section{REFERENCE}

American Society of Heating, Refrigeration and Air Conditioning Engineers, 1995. "Handbook of Applications, ASHRAE, Atlanta, GA.

American Society of Heating, Refrigeration and Air Conditioning Engineers, 1985. "Handbook of Fundamentals", ASHRAE, Atlanta, GA, pp. 25.6.

Behrends, L. L., 1978. "Waste Heat Utilization for Agriculture and Aquaculture", Tennessee Valley Authority.

Department of Defense, 1978. "Engineering Weather Data," AFM 88-29, TM 5-785, NAUFAC, pp.. 89, Washington, DC.

Johnson, W. C., 1978. "Culture of Freshwater Prawns Using Geothermal Waste Water", Geo-Heat Center, Klamath Falls, OR.

Lauer, B. E., undated. "Heat Transfer Calculations," Handbook reprinted from the Oil and Gas Journal, pp.. 9. 
Stoever, H. J., 1941. "Applied Heat Transmission," McGraw-Hill, New York, NY.
Wolf, H., 1983. "Heat Transfer", Harder \& Row, New York, NY, pp.. 254. 
SECTION 5 - AQUACULTURE BIBLIOGRAPHY 


\section{Section 5 \\ AQUACULTURE BIBLIOGRAPHY}

The publications listed below were obtained from the National Sea Grant Research Comprehensive Bibliography (www.mdsg.umd.edu/NSGO/research/aquaculture/index.html) Website and is not a complete listing of all the publications available. This bibliography would be useful for anyone interested in Aquaculture. The literature is current to July, 1997. These publications can be requested from the National Sea Grant Depository (nsgd.gso.uri.edu) or from each of the Sea Grant programs. The first part of the Document \# is an abbreviation for the specific Sea Grant program. The abbreviations and addresses for the Sea Grant programs are included at the end of section seven (p7.10).

\section{Aquaculture - General}

1996. "Making a Difference in Aquaculture". Document \# RIU-G-96-009.

1993. "Aquaculture and Seafood Safety". Document \# WISCU-G-93-004.

Weber, J. C.; Silva, Robert; Jensen, LeNore. 1993. "Integrated Aquaculture Project". 44pp. Document \# NHU-T-93-004.

Swann, Ladon. 1990. "A Basic Overview of Aquaculture." 11pp. Document \# ILIN-G-90-001. Ness Howard. 1976. "Costs and Benefits of Public Aquaculture Programs." 4pp. Document \# AKUZ-76-014.

Malouf, Robert E. 1981. “Aquaculture: Food for Our Future.” Document \# NYSGI-Z-81-007.

Gates, John M.; Mueller, J. J. 1975. "Optimizing the Growth and Marketing of Fish in a Controlled Environment.” Marine Technology Society, 9(5):0013-0016. Document \# RIU-R-75-008.

\section{Bioeconomics/economics}

Adamas, Charles M. 1986. “Aquaculture in Florida: General Economic considerations.” 17 pp. Document \# FLSGP-T-86-008.

Adams, Chuck. 1993. "Is Your Aquaculture Plan Commercially Feasible?" Splash, Florida Aquaculture Marketing News, 4(2):3. Document \# FLSGP-R-93-022.

Allen, P. Geoffrey; Botsford, Louis W.; Schuur, Anthonie M.; Johnston, Warren E. 1984. "Bioeconomics of Aquaculture". Developments in Aquaculture and Fisheries Science, Volume 13. 351 pp. Document \#CUIMR-O-84-001. 
Anderson, James Lavalette. 1983. "Bioeconomic Interaction Between Aquaculture and the Common Property Fishery with Application to Northwest Salmon Resources." Document \# CUIMR-X-83-004.

Botsford, Louis W.; Gossard, T. W. 1978. "Implications of Growth and Metabolic Rates on Costs of Aquaculture." World Mariculture Society Ninth Annual Meeting Proceedings, Atlanta Georgia. Pp. 413-423. Document \# CUIMR-R-78-031.

Botsford, Louis W.; Rauch, H. E.; Shleser, Robert. 1974. "Application of Optimization Theory to the Economics of Aquaculture." World Mariculture Society Fifth Annual Workshop Proceedings, Charleston, SC. Pp 387-401. Document \# CUIMR-R-74-038.

Davidson, Jack R. 1972. "Economics of Aquaculture Development." 8 pp. Document \# WISCU-Z$72-032$.

Griffin, Wade L.; Adams, Charles M.; Jensen, Linda A. 1982. "A Generalized Budget Simulation Model for Aquaculture." Document \# TAMU-H-82-003.

Karp, Larry; Sadeh, Arye; Griffin, Wade L. 1986. "Cycles in Agricultural Production: The Case of Aquaculture." American Journal of Agricultural Economics, 68(3):553-561. Document \# TAMU-R86-017.

MacDonald, C. R.; Meade, Thomas Leroy; Gates, John M. 1975. "A Production Cost Analysis of Closed System Culture of Salmoniods.” 11 pp. Document \# RIU-T-75-006.

Pollnac, Richard B., Peterson, Susan; Smith, Leah J. 1982. "Elements in Evaluating Success and Failures in Aquaculture Projects." Aquaculture Development in Less Developed Countries: Social, Economic and Political Problems, L. J. Smith and S. Peterson (EDS.). Pp. 131-145.

Document \# WHOI-R-82-019.

Rauch, Herbert E., Botsford, Louis W.; Shleser, Robert A. 1975. "Economic Optimization of an Aquaculture Facility." IEEE Transactions on Automatic Control, AC-20(03):0310-0319.

Document \# CUIMR-R-75-053.

\section{Culture Systems : Ponds}

Harrell, Reginal M.; Wester Donald W. 1991. "Farm Pond Management: Increasing Production Through Fertilization". 7pp. Document \# MDU-G-91-003.

Leffler, Merrill. 1991. "Farming Fish in Open Ponds". Document \# MDU-V-91-001.

Madenjian, Charles; Rogers, Gary L.; Fast, Arlo W. 1988. "Predicting Nighttime Dissolved Oxygen Loss in Aquaculture Ponds". Canadian Journal of Fisheries and Aquatic Sciences, 45(10)1842-1847. Document \# HAWAU-R-85-005. 
Yates, Michael Edward. 1988. "The Relationship Between Engineering Design and Construction Costs of Aquaculture Ponds". 2pp. Document \# TAMU-X-88-001.

Snyder, Fred L. 1994. "Short Article about Farm Ponds". Document \# OHSU-G-94-008.

\section{Broodstock}

Gearheard, James. 1981. "Captive Broodstock Problems at Washington Department of Games Hatcheries." Pp. 34-35. Document \# WASHU-Z-81-010.

Harrell, Reginal M. 1992. "Stress Mitigation by Use of Salt and Anesthetic for Wild Striped Bass Captured for Brood Stock." The Progressive Fish-Culturist, 54:228-233. Document \# MDU-R-92013.

Harrell, Reginal M.; Moline, Mark A. 1992. "Comparative Stress Dynamics of Brood Stock Striped Bass "Morone Saxatilis" Associated with Two Capture Techniques." Journal of the World Aquaculture Society, 23(1):58-63. Document \# MDU-R-92-021.

Hedgecock, Dennis; Moffett, William L.; Borgeson, W.; Nelson, Keith. 1978. "Progress and Problems in Lobster Broodstock Development." World Mariculture Society Ninth Annual Meeting Proceedings, Atlanta, Georgia, January 3-6. Pp. 497-506. Document \# CUIMR-R-78-029.

Hickey, Paul L. 1981. "Broodstock Selection Program at Aquasea Farms, Inc. 2 pp.

Document \# WASHU-Z-81-007.

Lund, Dennis Sheldon. 1981. "Jackson College Pink Salmon Broodstock Experience." 2pp.

Document \# WASHU-Z-81-004.

\section{American Eel}

Field, Donald W.; Eversole, Arnold G. 1982. "Parasite Levels of Stocked Glass Eel and Elver Satges of American Eel." World Mariculture Society. Journal, 13:268-273. Document \# SCSGC-R-82-010.

Foster, John E., Rickards, William L. 1981. "Teaching Young American Eels to Consume Prepared Feeds." 5 pp. Document \# NCU-T-81-003.

\section{American Lobster}

Gallagher, Margie Lee; Bayer, Robert C; Leavitt, Dale F.; Rittenburg, James H. 1979. "Effects of Protein-Energy Ratios on Growth of American Lobsters ("Homarus Americanus"). World Mariculture Society, Proceedings of the Annual Workshop, 10(NA):07 46-0750. Document \# MEU-R-79012.

Gallager, Margie Lee; Leavitt, Dale F.; Bayer, Robert C.; Rittenburg, James H. 1984. “A comparison of Techniques for the Measurement of Growth in Adult Lobsters." Aquaculture, 38:195-199. Document \# MEU-R-84-003. 
Hedgecock, Dennis; Nelson, Keith; Shleser, Robert A. 1976. "Growth Differences Among Families of the Lobster, "Homarus Americanus"." In: World Mariculture society Seventh Annual Workshop Proceedings. 34pp. Document \# CUIMR-R-76-013.

Kendall, Richard A.; Van Olst, Jon C.; Carlberg, James M. 1982. "Effects of Chelae Immobilization on Growth and Survivorship for Individually and Communally Raised Lobsters, "Homarus Americanus"." Aquaculture, 29:359-372. Document \# CUIMR-R-82-059.

\section{Channel Catfish}

Duhamel, G. E.; Kent, M. L.; Dybdal, N. O.; Hedrick, R. P. 1986. "Henneguya Exilis" Kudo Associated with Granulomatous Branchitis of Channel Catfish "Ictalurus Punctatus" (Rafinesque). Veterinary Pathology, 23:354-363. Document \# CUIMR-R-86-026.

Schmittou, H. R. 1970. "The Caged Culture of Channel Catfish." Document \# TAMU-Z-70-029.

\section{Freshwater Prawns}

Goodwin, Harold L., Hanson, Joe A. 1974. "The Aquaculture of Freshwater Prawns ("Macrobrachium" Species). 95 pp. Document \# OCEI-WA-74-001.

Hino, Wendell M. 1978. "Aquaculture: The Problems, Potential, and Developments in Raising "Macrobrachium Rosenbergii"." Document \# HAWAU-Z-78-010.

Hunter, Jay Van-Huizen. 1979. "Freshwater Shrimp Farming in the Continental United Sates: An Introduction to the Giant Malaysian Prawn. Farm Pond Harvest, (NA):0011-0030, Spring, 1979. Document \# LSU-R-79-001.

Malecha, Spencer R.; Buck, D. H.; Baur, R. J.; Onizuka, D. R. 1981. "Polyculture of the Freshwater Prawn, "Macrobrachium Rosenbergii", Chinese and Common Carps in Ponds Enriched with Swine Manure 1. Initial Trials." Aquaculture, 25(NA):0101-0116. Document \# HAWAU-R-81-009.

Malecha, Spencer R.; Polovina, Jeffery, J.; Moav, R. 1981. "Multi-State Rotational Stocking and Harvesting System for Year-Round Culture of the Freshwater Prawn, "Macrobrachium rosenbergii"." 26 pp. Document \# HAWAU-T-81-002.

Sandifer, Paul A.; Hopkins, J. S.; Smith, T. I. J. 1977. "Production of Juveniles: Status of Macrobrachium Hatcheries, 1976. Shrimp and Prawn Farming in the Western Hemisphere Sate of the Art reviews and Status Assessments, J. Hanson and H. Goodwin (EDS.). Pp. 220-231.

Document \# SCSGC-R-77-003.

Sick, Lowell V.; Beaty, Helen. 1974. "Culture Techniques and Nutrition Studies for Larval Stages of the Giant Prawn, "Macrobrachium Rosenbergii"." 30 pp. Document \# GAUS-T-74-006 
Smith, Theodore I. J.; Sandifer, Paul A.; Trimble, William C. 1974. "Progress in Developing a Recirculating Synthetic Seawater Hatchery for Rearing Larvae of "Macrobrachium Rosenbergii"." Food-Drugs from the Sea Proceedings, H. Webber and G. Ruggieri.

Document \# SCSGC-R-74-005.

Smith, Theodore I. J.; Jenkins, Wallace, E.; Sandifer, Paul A. 1982. "Enclosed Prawn Nursery Systems and Effects on Stocking Juvenile "Macrobrachium Rosenbergii" in Ponds." Journal of the World Mariculture Society. 14:111-125. Document \# SCSGC-R-82-013.

Smith, Theodore I. J.; Sandifer, Paul A.; Jenkins, Wallace E. 1980. "Growth and Survival of Prawns, "Macrobrachium Rosenbergii", Pond-Reared at Different Salinities. Giant Prawn Farming, H. B. New (ED.) Document \# SCSGC-R-80-003.

Smith, Theodore I. J.; Sanifer, Paul A.; Jenkins, Wallace E.; Stokes, Alvin D. 1981. "Effects of Population Structure and Density at Stocking on Production and Commercial Feasibility of Prawn ("Macrobrachium Rosenbergii") Farming in Temperature Climates." World Mariculture Society Journal, 12(1):233-250. Document \# SCSGC-R-81-004.

Zielinski, Paul B.; Castro, Walter Ernest; Sandifer, Paul Alan. 1974. "The evaluation and Optimization of "Macrobrachium" Shrimp Larvae Tank Designs and Support Systems. In: World Mariculture Society Fifth Annual Workshop Proceedings. Document \# SCMRC-R-74-00.

1974. "Prawn Culture Systems". 8 pp. Document \# OCEI-Z-74-008.

\section{Lake Trout}

Barry, Terence P.; Lapp, Anita F.; Kayes, Terrence B.; Malison, Jeffery A. 1993. "Validation of a Microtitre Plate Elisa for Measuring Cortisol in Fish and Comparison of Stress Responses of Rainbow Trout ("Oncorhynchus Mykiss") and Lake Trout ("Salvelinus Namaycush"). Aquaculture, 117:351363. Document \#WISCU-R-93-018.

Cheng, Li-Lin; Bowser, P. R.; Spitsbergen, J. M. 1993. "Development of Cell Cultures Derived from Lake Trout Liver and Kidney in a Hormone-Supplemented, Serum-Reduced Medium. Journal of Aquatic Animal Health, 5:119-126. Document \# NYSGI-R-93-007.

Marsden, J.E.; Krueger, C. C. 1991. "Spawning by Hatchery-Origin Lake Trout ("Salvelius Namaycush") in Lake Ontario: Data from Egg Collections, Substrate Analysis, and Diver Observations. Canadian Journal of Fisheries and Aquatic Sciences, 48(12):2377-2348.

Document \# NYSGI-R-91-031.

\section{Pink Shrimp (Pennaeus Dourarum)}

Anderson, Lee G.; Tabb, Durbin C. 1971. "Some Economic Aspects of Pink Shrimp Farming in Florida". Document \# MIAU-Z-71-014. 
Rickards, William L. 1971. "Studies of the Use of Vertical Substrates for Improving Production in the Culture of Pink Shrimp,"Penaeus Duorarum","Burkenroad. 152pp. Document \# MIAU-T-71-006.

Tabb, Durbin C.; Yank, Won Tack; Hirono Yosuke; Heinen, John. 1972. "A Manual for Culture of Pink Shrimp "Penaeus Duorarum", From Eggs to Post Larvae Suitable for Stocking". 59 pp.

Document \# MIAU-H-72-001.

Thorhaug, Anitra; DeVany, Tom; Murphy, Barbara. 1971. "Refining Shrimp Culture Methods: The Effect of Temperature on Early Stages of the Commercial Pink Shrimp". Document \# MIAU-Z-71015 .

\section{Striped Bass}

Carlberg, James M; Van Olst, Jon C.; Massingill, Michael J.; Hovanec, Timothy A. 1983. "Intensive Culture of Striped Bass: A review of Recent Technological Developments".

Document \# MDU-Z-83-020

Grulich, Ron; Oesterling, Mike. 1984. "Intensive Culture of Stripped Bass: Review, Recommendations and Feasibility". 66 pp. Document \# VSGCP-T-84-003

Harrell, Reginal M. (ED.); Kerby, Jerome Howard (ED.); Minton, R. Vernon (ED.). 1990. "Culture and Propagation of Striped Bass and Its Hybrids". 323pp. Document \# AFS-H-90-001

Harrell, Reginal M. 1988. "The Culture of Striped Bass and its Hybrids in Cages". 8pp. Document \# MDU-G-88-003

Jenkins, Wallace; Smith, Theodore I. J. 1988. "Performance of Striped Bass and its Hybrids in Aquaculture Systems. 1pp. Document \# SCSGC-R-88-013.

Kerby, Jerome Howard. 1986. "Striped Bass and Striped Bass Hybrids". Culture of Nonsalmonid Freshwater Fishes, Robert R. Stickney (ED.). Pp 127-188. Document \# NCU-R-86-007.

\section{Tilapia}

Acosta-Nassar, Marce V.; Morell, Julio M.; Corredor, Jorge E. 1994. "The Nitrogen Budget of a Tropical Semi-Intensive Freshwater Fish Culture Pond". Journal of the World Aquaculture Society, 25(2):261-270. Document \# PRU-R-94-009.

Anderson, Robert G.; Griffin, Wade L.; Stickney, Robert R.; Whitson, RobertE. 1978. "Bioeconomic Assessment of A Poultry and Tilapia Aquaculture System." 15pp. Document \# TAMU-Z-78-014.

Arias, Santiago; Wiscovich, Saul. “Aquaculture: Technical Facts for its Development.” 13pp. Document \# PRU-G-89-003. 
Homziak, Jurij; Posadas, Benedict C. 1989. "A Preliminary Survey of Tilapia Markets in North America." Proceedings of the 42nd Annual Gulf and Caribbean Fisheries Institute, Ocho Rios, Jamaica, November 1989. PP. 83-102. Document \# MASGC-R-89-011.

Teruel, Saul Wiscovich. 1993. "Tilapia Culture in Cages." 10 pp. Document \# PRU-G-93-021. 
SECTION 6 - AQUACULTURE GLOSSARY 


\section{Section 6 \\ AQUACULTURE GLOSSARY}

Aquaculture - The production and sale of farm-raised aquatic plants and animals

Bacteria - Microscopic animal life, some kinds of which are responsible for the decay of dead materials and wastes.

Biofilter - Component of recirculating systems consisting of a large surface area upon which bacteria grow. These live on fish waste products, breaking them down into forms much less harmful to fish.

Brackish Water - a mixture of fresh and salt water.

Broodfish - Fish kept for egg production, including males. Broodfish produce the fertilized eggs which go to hatcheries.

Dissolved Oxygen - Oxygen dissolved poorly in water and is often in short supply for aquatic animals. Warm water holds even less oxygen than cold water.

Extensive Culture - outdoor, low density culture usually involving large ponds and/or flow-through raceways.

Fertilizer - a substance added to water to increase the production of natural fish food organisms.

Fingerlings - Young fish from one inch in length up to one year of age. This stage comes after the fry stage. Fish weighing 60 pounds per 1,000 fish and less.
Fry - young fish from the time of hatching up to 1 inch in length. Fish weighing 60 pounds per 1,000 fish and less.

Grow-Out Pond/Facility - a pond or other facility used to grow aquatic animals to marketable size.

Integrated Aquaculture - aquaculture systems integrated with livestock and/or crop production. For example, using animal manures to fertilize a pond to enhance fish production and water from the pond to irrigate a garden.

Intensive Culture - indoor, high density culture usually involving recirculation of water and biofilters.

Large Foodsize - Fish weighing over three pounds.

Large Stockers - Fish weighing over 180 pounds to 750 pounds per 1,000 fish.

Levee Ponds - Standing water impoundments built by excavating the pond area to a shallow depth and using the soil obtained to build a perimeter of levees or dykes.

Male Hormone - a substance that, when fed to Tilapia fry, induces undifferentiated tissue to develop into male gonads (testes).

Manual Sexing - examining a fish to determine its sex. 
Manufactured Food - commercially processed food for fish or livestock.

Medium Foodsize - Fish weighing over one and one-half pounds to

three pounds.

Mixed-Sex Culture - culture of males and females in the same grow-out facility.

Monosex Culture - culture of all-male fish for market.

Mouth-Brooder - a fish that hatches its eggs in its mouth.

Off-flavor - Aquatic animals can absorb and take on bad flavors from the water in which they live. These musty, muddy or otherwise undesirable flavors usually come from substances put out by certain species of microscopic plants (phytoplankton).

Partial Harvesting - periodic harvesting of a portion of the fish from a culture facility during a culture cycle.

Phytoplankton - The plant component of plankton.

Plankton - the various, mostly microscopic, aquatic organisms (plants and animals) that serve as food for larger aquatic animals and fish.

Poly Culture - simultaneous culture of two or more aquatic species with different food habits.

Predacious Fish - a fish species that eats other fish as food.

Raceways - Long channels through which large amounts of new water flow continuously and are then discarded. Usually built of concrete, these can also be earthen channels or long tanks of other materials.

Recirculating Systems - Tank systems which rely on biofilters to break down harmful fish waste products so water can be reused.

Seine - A long net used to capture fish.

Small Foodsize - Fish weighing over threefourths pound to one and one-half pounds.

Small Stockers - fish weighing over 60 pounds to 180 pounds per 1,000 fish.

Spawning - the act of depositing eggs and producing young.

Substrate Spawner - a fish that lays its eggs on some form of substrate or surface where they will hatch.

Turnover - Mixing of top and bottom water that can lead to fish kills, especially in watershed ponds. During the summer a cold bottom layer of water lacking in oxygen develops. In fall, the bottom and top layers can suddenly mix or "turnover".

Watershed Ponds - Impoundments built by damming ravines or small valleys. Runoff from the surrounding watershed fills the ponds.

Water Quality - The degree of suitability of water for growing fish and other aquatic organisms. Water high in dissolved oxygen and low in animal wastes such as ammonia is generally considered to be high quality. Other factors also come into play such as alkalinity, chlorides and harmful substances such as iron and hydrogen sulfide.

Zooplankton - an animal component of plankton. 
SECTION 7 - STATE/REGIONAL/UNIVERSITY/EXTENSION AQUACULTURE OFFICES 


\section{Section 7 \\ STATE/REGIONAL/UNIVERSITY/EXTENSION AQUACULTURE OFFICES}

\section{Extension Contact in Aquaculture}

\author{
Alaska \\ Marine Advisory Program \\ University of Alaska-Fairbanks \\ 2221 E. Northern Lights Blvd. \#10 \\ Anchorage, AK 99508-4140 \\ (907) 274-9691
}

\section{Arizona}

Environmental Research Lab

University of Arizona

2601 East Airport Drive

Tucson, AZ 85706-6985

(520) $741-1990$

Arizona Cooperative Extension

University of Arizona

301 Forbes Bldg.

Tucson, AZ 85721

(602) 621-5308

\section{California}

Dept. Of Animal Science

University of California-Davis

Davis, CA 95616

(916) $752-7689$

U.C. Cooperative Extension

Sea Grant Marine A'dvisory Prog.

2 Commercial Street, Suite 4

Eureka, CA 95501

(707) 527-2621

UC-Cooperative Extension Sea Grant 2604 Ventura Avenue

Room 100P

Santa Rosa, CA 95403-2894

(707) 527-2621
UC Sea Grant Extension Program

Area Marine Advisor

PO Box 440

Moss Landing, CA 95039

(408) 633-7266

\section{Colorado}

Fishery \& Wildlife Biology

Colorado State University

239 Wager Building

Fort Collins, CO 80523

(303) 491-5091

Cooperative Extension

Colorado State University

1 Administration Building

Fort Collins, CO 80523

(303) 491-6208

\section{Idaho}

Aquaculture Research Institute

University of Idaho

Moscow, ID 83843

(208) 885-5830

Twin Falls County Extension

University of Idaho

246 Third Ave. East

Twin Falls, ID 83301

(208) 734-9645

\section{Montana}

Conservation Education Division

Montana Dept. Of fish Wildlife and Parks

Helena, MT 59620

(406) 444-4038 
Fisheries Div

Montana Dept of Fish, Wildlife and Parks 1420 E. Sixth Avenue

Helena, MT 59620

(406) 444-2449

Department of Biology

Montana State University

Bozeman, MT 59717-0001

(406) 994-2492

College of Agriculture/Extension Service

Montana State University

Bozeman, MT 59717

(406) 994-3681

\section{Nevada}

Nevada Cooperative Extension

2345 Red Rock Street, Suite 330

Las Vegas, NV 89102-3157

(702) 251-7531

Nevada Dept. Of Wildlife

PO Box 10678

Reno, NV 89520

(702) 688-1500

New Mexico

Cooperative Extension Service

New Mexico State University

Box 30003, Dept 3AE

Las Cruces, NM 88003-8003

(505) 646-1164

Dept of Fishery \& Wildlife Sciences

PO Box 30003, Campus Box 4901

New Mexico State University

Las Cruces, NM 88003

(505) 646-1707
Public Affairs Division

Dept. Of Game and Fish

PO Box 25112

Sante Fe, NM 87503

(505) 827-7911

Oregon

Astoria Seafood Laboratory

Oregon State University

250 - 36th Street

Astoria, OR 97103

(503) 325-8027

Extension Office

2204 4th St.

Tillamook, OR 97141

(503) 842-3433

\section{South Dakota}

Interagency Coordinator

Dept of Game, Fish \& Parks

445 E. Capitol

Pierre, SD 57501

(605) 773-4196

\section{Utah}

Aquatic Section

Utah Division of Wildlife Research

1594 West North Temple, Suite 2110

PO Box 146301

Salt Lake City, UT 84114-6301

(801) 538-4760

College of Natural Resources

Dept of Fish \& Wildlife

Utah State University

Logan, UT 84322-5210

(801) 797-2459

Wildlife Damage Specialist

Department of Fisheries and Wildlife

Utah State University

Logan, UT 84322-5210

(801) $797-2536$ 
Washington

Cooperative Extension

Washington State University

PO Box 646230

411 Hulbert

Pullman, WA 99164-6230 
Federal Fishery Assistance Offices

\author{
Alaska \\ USFWS, Kenai Fishery Resource Office \\ Gary Sonnevil \\ Project Leader \\ PO Box 1670 \\ Kenai, AK 99611 \\ (907) 262-9863
}

\section{California}

Northern Central Valley

Fish and Wildlife Office

10950 Tyler Road

Red Bluff, CA 96080

(916) $527-3043$

US Fish and Wildlife Service

Klamath River FWO

Ron Iverson

PO Box 1006

Yreka, CA 96097-1006

(916) 842-5763

\section{Idaho}

US Fish and Wildlife Service

Idaho Fishery Resource Office

Howard L. Burge, Project Leader

PO Box 8

Ahsahka, ID 83520

(208) 476-7242

\section{Montana}

US Fish \& Wildlife Service

Creston Fish and Wildlife Center

Mark Maskill \& Wade Fredenberg 780 Creston, Hatchery Road

Kalispell, MT 59901

(406) 768-6868

\section{Washington}

Vancouver

Frederick E. Olney, Proj. Leader

Suite I

9317 Highway 99

Vancouver, WA 98665

(306) 696-7605

\section{Wyoming}

Lander FWMAO

David L. Skates

Project Leader

170 North First St.

Lander, WY 82520

(307) 332-2159 


\section{Additional Sources of Information for Aquaculturists}

Alaska

Brian Paust

Alaska Marine Advisory Program

University of Alaska

PO Box 1329

Petersburg, AK 99833

(907) 772-4431

State of Alaska

Dept. Of Natural Resources

3601 C St., Suite 1080

Anchorage, AK 99503-5937

(907) 269-8546

\section{California}

California Dept of Fish \& Game

1416 Ninth St.

Sacramento, CA 95814

(916) 653-9583

Idaho

Rangen Aquaculture Research Center 2928B S 1175 E

Hagerman, ID 83332

(208) 837-6191

\section{Oregon}

Fish Division

Oregon Dept of Fish and Wildlife

PO Box 59

Portland, OR 97207

(503) 872-5632

\section{South Dakota}

Fisheries Staff Specialist

South Dakota Game, Fish and Parks

Foss Building, 523 E Capitol

Pierre, SD 57501

(605) 773-4508

Utah

US Fish and Wildlife Service

Ouray National Fish Hatchery

266 W. 100 North

Vernal, UT 84078

(801) 789-4078

Dr. Gar W. Workman

Applied Ecological Services, Inc.

Clocktower Plaza, Suite 222

550 North Main Street

Logan, UT 84321

Washington

John Kerwin

Washington Dept of Fish and Wildlife 600 N. Capitol Way

Olympia, WA 98501-1091

(206) $902-2623$ 


\section{Alaska}

Alaskan Shellfish Growers Assoc.

PO Box 7

Moose Pass, AK 99631

(907) 288-3667

Southern Southeast Regional

Aquaculture Association, Inc.

2721 Tongass

Ketchikan, AK 99901

(907) 225-9605

\section{California}

California Aquaculture Association

PO Box 1004

Niland, CA 92257

(760) 359-3474

\section{Colorado}

Colorado Aquaculture Assoc.

Box 27

Leadville, CO 80461

(719) 486-1075

\section{Idaho}

Idaho Aquaculture Assoc.

PO Box 28

Buhl, ID 83316

(208) $543-4898$

Washington

WA Farmed Salmon Commission

PO Box 5305

Bellingham, WA 98227

(360) 671-1997

Washington Fish Growers Association

10420 173rd Ave SW

Pochester, WA 98579

(360) 273-5890

Washington Pacific Coast Oyster Growers Assoc.

120 State Ave NE \#142

Olympia, WA 98501

(360) 754-2744 
State Aquaculture Coordinators

\section{California}

Gerald W. Miller

Principal Biologist

Dept. Of Food and Agriculture

1220 N. St.

Division of Plant Industry

Sacramento, CA 95814

(916) 654-0768

\section{Idaho}

Dr. Phillip Mamer

Aquaculture Coord.

Division of Animal Industries

Idaho Dept. Of Agriculture

Box 7249

Boise, ID 83707

(208) $332-8560$

\section{Montana}

Darla Anderson

Montana Dept. Of Agriculture

PO Box 200201

Helena, MT 59620-0201

(406) 444-2402

\section{Oregon}

Dalton Hobbs, Int'1 Trade Mgr.

Oregon Dept of Agriculture

Agric. Development and Marketing Div.

121 SW Salmon Street, Suite 240

Portland, OR 97204-2987

(503) 229-6734

\section{Nevada}

Nevada Dept. Of Agriculture

350 Capitol Hill Ave.

PO Box 11100

Reno, NV 89510

(702) 789-0180

Utah

Russell Lee, DVM

Fish Health Specialist

Utah Dept of Agriculture

350 North Redwood Rd.

PO Box 146500

Salt Lake City, UT 84114-6500

(801) 538-7029 
Diagnostic Services Available

\section{California}

Fish Disease Lab

California Dept of Fish and Game

407 West Line Street

Bishop, CA 93514

(760) 872-1134

Dept of Medicine and Epidemiology

School of Veterinary Medicine

University of California

Davis, CA 95616

(916) 752-3411

Colorado

Wildlife Pharmaceuticals, Inc.

1401 Duff Drive \#700

Fort Collins, CO 80524

(970) 484-6267

\section{Idaho}

Idaho Dept. Of Fish and Game

1800 Trout Rd.

Fish Health Laboratory

Eagle, ID 83616

\section{Montana}

Fish Health Center

US Fish and Wildlife Service

920 Technology Blvd., Suite G

Bozeman, MT 59718-4001

(406) 582-8656

US Fish and Wildlife Service

Fish Technology Center 4050 Bridger Canyon Road

Bozeman, MT 59715-8713

\section{Oregon}

Dept. Of Microbiology

Nash Hall 220

Oregon State University

Corvallis, OR 97331-3804

(541) $737-4753$

\section{Utah}

Zoology Department

153 WIDB

Brigham Young University

Provo, UT 84602

(801) 378-2495

(801) 378-2006

Washington

Olympia Fish Health Center 3704 Griffin Lane SE, Suite 101

Olympia, WA 98501

(360) 753-9046

Troutlodge, Inc.

PO Box 1290

Sumner, WA 98390

(253) 863-0446

US Fish and Wildlife Service

MAKAH NFH

PO Box 739

Nesh Bay, WA 98357

(360) 645-2521

Wyoming

Game and Fish Laboratory

University of Wyoming

PO Box 3312

Laramie, WY 82071

(307) 766-5618 


\section{Chief of Fisheries}

State of Wyoming

Wyoming Game and Fish Dept.

5400 Bishop Blvd.

Cheyenne, WY 82006

(307) 777-4559 
Sea Grant Program Abbreviations and Addresses

AKU

Alaska Sea Grant College Program

University of Alaska Fairbanks

PO Box 755040

Fairbanks, AK 99775-5040

(907) 474-7086

(907) 474-6285 (fax)

www.uaf.alaska.edu/seagrant/

\section{AZU}

Dept. Of Veterinary Science

University of Arizona

Tucson, AZ 85721

(602) 621-8414

CUIMR

California Sea Grant

University of California/San Diego

9500 Gilman Drive

La Jolla, CA 92093-0232

(619) 534-444

(619) 453-2948 (fax)

www-csgc.ucsd.edu/

HAWAU

University of Hawaii

Sea Grant College Program

1000 Pope Road, MSB 200

Honolulu, HI 96822

(808) 956-7410

www.soest.hawaii.édu/SEAGRANT/

\section{NCRI}

National Costal Resources Research \&

Development Inst.

528 Southwest Mill, Suite 222

PO Box 751

Portland, OR 97207

(503) $725-5725$

\section{ORESU}

Oregon Sea Grant

Oregon State University

AdS 402

Corvallis, OR 97331-2134

(541) $737-2716$

(541) $737-2392$

seagrant.orst.edu

\section{OREXT}

Publications Orders

Agricultural Communications

Oregon State University

Ads 422

Corvallis, OR 97331-2119

(541) $737-2513$

seagrant.orst.edu

SCU

Southern California Sea Grant

University of Southern California

University Park

Los Angeles, CA 90089-0373

(213) $740-1961$

(213) 740-5936 (fax)

www.usc.edu/dept/seagrant/seagrant.html

\section{WASHU}

Washington Sea Grant, HG-30

University of Washington

3716 Brooklyn Avenue, N. E.

Seattle, WA 98105-6716

(206) 543-6600

(206) 685-0380 (fax)

www.wsg.washington.edu/ 
SECTION 8 - STATE AQUACULTURE PERMIT REQUIREMENTS

This section contains information from the publication entitled "State/Territory Permits and Regulations Impacting the Aquaculture Industry, 1995." The information for this section was found through the website http://ag.ansc.purdue.edu/aquanic/publicat/state $/ \mathrm{md} / \mathrm{md} . h \mathrm{htm}$ under the AquaNIC State Publications for Maryland. The direct link to the publication is http://ag.ansc.purdue.edu/aquanic/publicat/state/md/perm.htm

The report provides an overview of regulations and permits by individual states and territories which concern the aquaculture industry. Most of the listings are summarized with pertinent information and contact information to help in the user's investigation. This publication was intended for informational purposes. Interested parties should contact appropriate agencies directly for current information or contact the office of your state aquaculture coordinator. 


\section{INTRODUCTION}

The Aquaculture Act of 1980 called for a compilation of regulations and permits impacting the aquaculture industry. During the years that followed, several projects at state and regional levels have been undertaken to accomplish this task. Although each of these were valuable in their own right, none provided a comprehensive picture of all state and territorial aquaculture regulations and permits. In 1993, the United States Department of Agriculture, Cooperative States Research Service, through the auspices of the Joint Subcommittee on Aquaculture, contracted with the Maryland Department of Agriculture to undertake this task, utilizing a new network of state aquaculture contacts that had been organized that year, the National Association of State Aquaculture Coordinators(NASAC). A research instrument previously developed and tested in Maryland and Washington was used for this purpose. The format provides critical information about specific permits which can be used to determine if they apply to various locations, technologies and species associated with aquaculture in a state. In place of full text of regulations, statutory and regulatory references are provided.

Early in the project it became evident that any documentation resulting from such a project would be dynamic and must be available in a form that can be updated.

Consequently, hard copy information is presented in a loose leaf format so data can be replaced in a cost effective manner. The information is also available in electronic form.

Before discussing pertinent information about permits, it is necessary to, first, determine the breadth of the topic to be covered. Although definitions of aquaculture are usually all inclusive, without regard to whether a facility is located in the mountains, plains or coastal areas, it becomes apparent that most states have confined their regulatory authority to upland or coastal zones rather than addressing open ocean state waters. Nevertheless, the United Nations Food and Agricultural Organization has developed a definition of the art and science of aquaculture:

". . . the farming of aquatic organisms including fish, mollusks, crustaceans and aquatic plants. Farming implies some form of intervention in the rearing process to enhance production, such as regular stocking, feeding, protection from predators, etc. Farming also implies individual or corporate ownership of the stock being cultured."

Most states and federal agencies use a general definition recognizing the culture of animals and plants in a water environment as being aquaculture. A drastically shortened and simplified definition is: "Aquaculture is the business of farming aquatic plants and animals". The variety of species raised, from alligators to zebra fish, and the different culture systems, earthen ponds to fiberglass tanks in climate controlled structures, coupled with development and investment from nontraditional agricultural businesses has caused considerable conflict with environmental and natural resource regulatory agencies and private groups. The newness and relative small size of U.S. aquaculture leads to conflict 
across lines of authority for many environmental and resource management agencies. These regulators are dealing with complex issues of human health, clean water, clean air, and ecosystem disruption. In most cases, they have responded by tweaking existing industrial permits to fit aquacultural operations.

Further exacerbating the situation, aquaculture frequently finds itself dealing with socioeconomic issues, history, and in some cases, a strong commercial fishery lobby. In many coastal states, aquaculture has been perceived as a threat, to be controlled through regulations, so it will remain a cottage industry much the same as the individual commercial fisherman.

Predictably, aquafarmers have protested the involvement of environmental and resource regulators and the additional costs and time delays associated with acquisition of permits. 


\section{EXECUTIVE SUMMARY}

An examination of permits and regulations impacting the aquaculture industry reveals certain broad categories of permits common to all states. With few, if any, exceptions all permits involve four issues:

$$
\begin{aligned}
& \text { Water Use } \\
& \text { Effluent Discharge } \\
& \text { Production } \\
& \text { Marketing }
\end{aligned}
$$

A central theme that transcends all of these issues is the protection of natural resources and wild stocks of aquatic animals.

\section{WATER USE}

In reality, there are very few permits which are exclusive to aquaculture. Most apply to other agricultural and industrial practices, as well. The following categories of water use permits generally reflect the application of existing regulations to aquaculture:

$\begin{array}{ll}\text { - } & \text { Ground/Surface Water Appropriation } \\ \text { - } & \text { Tidal Wetlands } \\ \text { - } & \text { Subm-tidal Wetlands } \\ \text { - } & \text { Water Column Leases } \\ \text { - } & \text { Well Construction } \\ \text { - } & \text { Pond Construction } \\ \text { - } & \text { Waterway Construction } \\ \text { - } & \text { Water Quality Certification }\end{array}$

It may appear that submerged land and water column leases fit more appropriately as production permits, however, their main purpose is to afford access to publicly controlled waters. Water quality certification is not a separate permit but is applied as part of the review process for certain state and federal permits. With the advent of recirculating systems, the demand for large quantities of water such as that used in trout raceways or catfish ponds has diminished. Consequently, some states which have established threshold levels of water use for traditional agricultural practices, such as irrigation or livestock watering, do not require separate permits for aquaculture. Maryland, for example, exempts businesses that use less than 10,000 gallons of water a day.

\section{EFFLUENT DISCHARGE}

The U.S. Environmental Protection Agency(EPA), through its National Pollutant Discharge Elimination System (NPDES) has set the stage for action by state environmental agencies to regulate effluent discharge from aquaculture facilities. Aquaculture operations culturing warm water species (catfish, crawfish, hybrid striped bass, shiners, ornamental 
fish, etc.) that discharge more than 30 days annually or produce more than 100,000 pounds $(45,454 \mathrm{~kg})$ round weight product annually must apply. Farms culturing more than 20,000 pounds $(9,000 \mathrm{~kg}$ ) of cold water species (salmonids) annually and providing at least 5,000 pounds $(2,272 \mathrm{~kg})$ of feed and discharging more than 30 days per year must apply. The U.S. EPA has delegated authority for issuing discharge permits to states adhering or adding further restrictions to these guidelines. According to information supplied for this study, all responding states but the following nine issue their own permits:
Arkansas
Maine New Mexico
Idaho
Massachusetts
Oklahoma
Illinois
New Hampshire
South Dakota

In addition to traditional discharge permits, some states require specialized ones. Arizona and Hawaii offer underground injection as a viable means of disposing of waste water and Hawaii may issue a zone of mixing permit in conjunction with an NPDES permit in coastal areas. As is true for pond construction permits, water quality certification is also part of the procedure necessary for obtaining a discharge permit. Maine is a good example of how a state can consolidate the procedure for obtaining several state and federal permits into one application process, thus, simplifying permitting for producers.

Responses to this study indicated a trend in discharge parameters of concern to states/territories. The following are listed in order of most frequently to least frequently appearing in regulations:

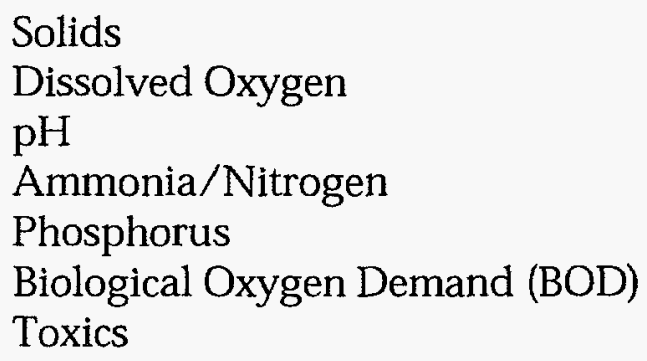

Enforcement of permit parameters varies widly among states. Generally, excess levels of most factors simply triggers corrective measures, but the least mentioned parameter, toxics, nearly always results in severe penalties or fines. The severity and immediacy of the damage (fish kills) that may result from toxic substances designed to benefit aquaculture operations, but accidentally discharged into the environment, frequently causes environmental agencies to react forcibly. Other factors which will impact how environmental agencies administer discharge permits include the method of disposal, discharge to surface/ground water or discharge via land/crop application. Additionally, some states consider aquaculture effluent as industrial waste, while others treat it the same as other agriculture manures.

Fee structures for aquaculture waste water discharge vary greatly among states. Most states have a flat application fee of between $\$ 50$ and $\$ 1000$, with an annual fee based on flow rates. Many charge $\$ 1$ per 1000 gallons per day. For flow through systems (raceways) this can become a substantial cost factor in an operation. Frequently, there are 
threshold levels of water flow under which no fee is charged. Maryland is one case in point. A fee is not levied for facilities discharging less that 1 million gallons a day. In reality, these fees are not the major concern in discharge permits. Compliance costs usually far exceed permit costs because the burden of monitoring is placed on the producer, not the agency. Environmental agencies frequently require growers to obtain the professional services of private certified chemistry labs to assure accuracy of submitted data, thus adding another layer of operating costs.

\title{
PRODUCTION
}

Permits which fall under the category of production tend to relate more to the species being propagated and frequently are the purview of fish and game rather than environmental agencies. They include:

\author{
Aquaculture Permits \\ Importation (shipping) \\ Species Permits \\ Propagation/Possession Permits \\ Collection Permits \\ Stocking Permits
}

Production permits and regulations include the aquaculture permit that is needed in most states simply to be in business. For the most part these permits are predicated on the facility being constructed in a manner that will preclude cultured fish from escaping into the wild. Most production permits are issued by fish and game or natural resource agencies specifically to protect wild stocks and, therefore, involve non-indigenous species and aquatic animal health provisions throughout. The regulatory strategies adopted by resource managers to permit ownership and sale of existing economically important species may involve onerous and costly tagging, and size or paperwork standards. The problem lies in the arena of enforcement. The farming of traditionally wild species complicates differentiation and identification of poached, out-of-season or undersized species. In several cases this problem has been resolved through clear documentation of ownership and sale from the farm to the buyer. The typical invoicing and delivery paperwork is sufficient to prove the legality of a farm raised species. In other cases, overpowering antipathy by special interest groups to the commercial sale of certain aquatic species will probably always be a barrier to farmers. A good example is large mouth black bass.

Non-indigenous species are generally defined as those species found beyond their natural range. Many aquacultural species fall into this category. There is growing national concern regarding the costs of controlling harmful non-indigenous species that have been intentionally or unintentionally introduced. The potential negative effects of these introductions include: spread of parasites and pathogens, disruption of natural ecosystems, and damage to existing agricultural and industrial operations. 
The final category of permits deals with activities associated with marketing or processing. In most states, the aquaculture permit is all that is needed for marketing, but some may require an additional permit or license, especially when dealing with shellfish. Marketing permits may include:

\author{
Wholesale Fish Dealers \\ Retail Sales License \\ Processing/Food Establishments \\ Fee Fishing (Pay Lake) License \\ Shellfish Depuration
}

Although shellfish depuration may be considered a production practice it is being included here as an activity which supports marketing of the final product. Because some states/territories have special concerns for specific species requirements, enforcement of marketing permits may vary from one species to another. This is evident in Maryland's requirement for containers and receipts associated with sales of striped bass (rockfish) to include a 14 digit alpha-numeric code that can be used to easily trace shipments of product back to the point of origin.

\title{
CONCLUSION
}

Most states have between four and ten permits or licenses required to be involved in aquaculture. Florida, New York and Texas each have over twenty. Eight of Florida's thirty six (36) permits deal with alligators and alligator products alone. It's fairly easy to point to instances which depict overregulation. But, as advocates for aquaculture, it is up to the industry to provide accurate information which will help create a comfort level for regulators. Regulators are building a database of information and an appreciation and understanding of aquaculture. As this report on state/territory permits and regulations impacting the aquaculture industry attests, numerous aquaculture specific permits have evolved to "fit" water farming and are being modified in positive ways to recognize the benign character of most aquacultural activities.

In many cases, state and federal agencies have been unfairly criticized for creating a labyrinth of permits and regulations. They are interpreting the will of legislators and special interest groups that charge them with broad mandates to protect the environment. A carefully applied combination of thorough preparation, common sense, logical thinking and professional behavior will result in timely decisions regarding permit applications.

Keep in mind the importance of regulatory agencies as sources of benefit for your community and the future of aquaculture in the United States. Much of the knowledge to maintain, spawn, grow-out and harvest aquacultural species has come from federal and state facilities that have been active since the 1930's. Natural resource managers are as interested, as the industry is, in insuring aquaculture's future in the United States but they have an additional charge of insuring this happens in a responsible manner. 
Become involved in the process.

Every state in which aquaculture flourishes has active trade organizations; industry advisory bodies to government and supportive legislators. To help yourself and the industry, seek these resources out, make use of their knowledge, provide creative answers to difficult questions and support responsible best management practices and quality assurance programs.

Aquaculture is thewave of the future and will provide nutritious seafood, valuable consumer products, important medical advances and improved quality of life for mankind on into the next century and beyond.

STATE/TERRITORY PERMITS AND REGULATIONS IMPACTING THE AQUACULTURE INDUSTRYis a compilation intended for informational purposes. It does not replace, supersede, or otherwise effect any agency rule, regulation, procedure, or responsibility or effect any regulatory or review requirement. Interested parties should contact appropriate agencies directly for current information or contact the office of your state or territory aquaculture coordinator identified in the appendix. The reader is also encouraged to begin an in-depth discussion with appropriate aquaculture coordinators, extension representatives, and aquaculture trade associations to develop an understanding of the environmental and resource management framework specific to your region. 


\section{ARIZONA}

1. NEW WELL CONSTRUCTION PERMIT

Issuing Agency: Department of Water Resources

15S. 15th Ave.

Phoenix, AZ 85004

(602)542-1550 FAX (602)256-0506

Statutory Reference: $\quad$ ARS 45-592.A. and ARS 45-596.

Regulatory Reference:

Activities Covered: Permit required to drill a new well.

Process:

Fees:

Other Information:

2. WELLS EXISTING - ID AND LOGS

Issuing Agency: Department of Water Resources

15S. 15th Ave.

Phoenix, AZ 85004

(602)542-1550 FAX (602)256-0506

Statutory Reference: $\quad$ ARS 45-593

Regulatory Reference:

Activities Covered: Previously existing wells must be identified and water use logs kept.

Process:

Fees:

Other Information:

3.

GRANDFATHER CERTIFICATION - WATER

MANAGEMENT DISTRICT

Issuing Agency: Department of Water Resources

15S. 15th Ave.

Phoenix, AZ 85004

(602)542-1550 FAX (602)256-0506

Statutory Reference: 
Regulatory Reference:

Activities Covered:

Process:

Fees:

Other Information:

4. CONTRACTS FOR USE OF PRIVATELY OWNED WATER SYSTEMS

Issuing Agency: Canal Systems and Irrigation Districts

Central Arizona Project/Salt River Project/Others

Statutory Reference:

Regulatory Reference:

Activities Covered: To utilize water from privately operated canal systems, individual negotiation with private entity must occur.

Process:

Fees:

Other Information:

5. WATER QUALITY CERTIFICATION

Issuing Agency: U.S. Army Corps of Engineers

Statutory Reference: Section 401 CWA

Regulatory Reference:

Activities Covered:

Process:

Fees:

Other Information: 
Issuing Agency: U.S. Army Corps of Engineers

Statutory Reference: Section 404 CWA

Regulatory Reference:

Activities Covered: To utilize waters of the State also identified as navigable waters.

Process:

Fees:

Other Information:

7. AQUACULTURE LICENSES - AQUACULTURE FACILITY, FEE.FISHING

FACILITY, AQUATIC ANIMAL TRANSPORTER AND PROCESSOR

Issuing Agency: $\quad$ Department of Agriculture

1688 W. Adams RM 321

Phoenix, AZ 85007

(602)542-4293 FAX (602)542-3244

Statutory Reference: $\quad$ ARS 3-2901 thru ARS 3-2913

Regulatory Reference: R3-2-1001 thru R3-2-1010

Activities Covered: Propagation, transportation, processing of aquatic animals/products, fee fishing operations.

Process: , Application and license fee submitted to Dept. of Agric.

Fees: $\quad \$ 100 /$ year (calendar)

Other Information:

8. IMPORT PERMIT Issuing Agency:

Department of Agriculture

1688 W. Adams RM 321

Phoenix, AZ 85007

(602)542-4293 FAX (602)542-3244

Statutory Reference: $\quad$ ARS 3-2901 to ARS 3-2913 
Regulatory Reference: R3-2-1010

Activities Covered: Importation of live aquatic animals - prior import permit required

Process:

Telephone ADA at (602)542-4293; information required which will include origin, destination, certification of lot/facility, type and quantity being shipped.

Fees:

None

Other Information:

9. WILDLIFE STOCKING PERMIT

Issuing Agency: Game and Fish Department 2222 W. Greenway

Phoenix, AZ 85023-4399

(602)942-3000 FAX (602)789-3920

Statutory Reference:

Regulatory Reference:

Activities Covered: Stocking of fish at locations not licensed by the Arizona Dept. of Agriculture as commercial fish farms.

Process:

Apply to regional or main office of Game and Fish Dept.

Fees:

None

Other Information:

10. WHITE AMUR STOCKING LICENSE

Issuing Agency: Game and Fish Department

2222 W. Greenway

Phoenix, AZ 85023-4399

(602)942-3000 FAX (602)789-3920

Statutory Reference: $\quad$ ARS 17.333.33

Regulatory Reference:

Activities Covered: Stocking of White Amur- triploid only

Process:

Apply to regional or main office of Game and Fish Dept. 
Fees:

$\$ 200 /$ annually

Other Information:

11. DISEASE CERTIFICATION

Issuing Agency: Department of Agriculture

1688 W. Adams RM 321

Phoenix, AZ 85007

(602)542-4293 FAX (602)542-3244

Statutory Reference: $\quad$ ARS 3-2901 to ARS 3-2913

Regulatory Reference: R3-2-1009

Activities Covered: Disease certification of facilities and lots

Process: $\quad$ Licenses - request made to ADA; producer pays expenses of certification. Out-of-State Facilities - must make own arrangements; producer pays expenses.

Fees: $\quad$ Licenses - varies depending on lab fees, travel expenses.

Other Information:

12. BEST MANAGEMENT PRACTICES FOR FEEDING OPERATIONS

Issuing Agency: Department of Environmental Quality

3033 N. Central Ave.

Phoenix, AZ 85012

(602)207-2300 FAX (602)207-2218

Statutory Reference: $\quad$ ARS 49-245-47; Section 318 CWA

Regulatory Reference:

Activities Coyered: Aquaculture facilities classified as feeding operations for purposes of regulation of water quality of water discharges.

Process:

Fees:

Other Information:

13. WATER DISCHARGE INTO RIVERS, LAKES, CREEKS

Issuing Agency: Department of Environmental Quality

3033 N. Central Ave.

Phoenix, AZ 85012

(602)207-2300 FAX (602)207-2218 
Statutory Reference: $\quad$ ARS 49-221, 222, 225

Regulatory Reference:

Activities Covered: In order to discharge into waters of the State, ADEQ standards must be followed.

Process:

Fees:

Other Information:

14. GROUND WATER RECHARGE PERMIT

Issuing Agency: Department of Water Resources

15S. 15th Ave.

Phoenix, AZ 85004

(602)542-1550 FAX (602)256-0506

Statutory Reference: $\quad$ ARS 45-652; ARS 49-221, 223, 224, 225.

Regulatory Reference:

Activities Covered: To direct any water (discharge) back into groundwater, must obtain permit and conform to DEQ aquifer water quality standards.

Process:

Fees:

Other Information: 


\section{CALIFORNIA}

\section{ARMY CORPS OF ENGINEERS "404" PERMI}

Issuing Agency: District Engineer

San Francisco District Corps of Engineers Regulatory Branch

211 Main St.

San Francisco, CA 94105

(415)974-0416

U.S. Army Corps of Engineers Regulatory Section

1325 J. Street

Sacramento, CA 95814-2922

(916)551-5100

Los Angeles District Corps of Engineers300 North Los Angeles St Los Angeles, CA 90012

(213)894-5606

Statutory Reference: Section 404, Federal Water Pollution Control Act, as Amended by the Clean Water Act of 1977. Section 9 and 10 of the River and Harbor Act of 1899.

Regulatory Reference:

Activities Covered: Location of a structure, excavation, or discharge of dredged or fill material into waters of the U.S.

Process:

Applicant submits Form 4345 to the Corps. Applications are processed in the order received. Corps prepares a Public Notice containing an Environmental Assessment of the proposed project and circulates it for 30 days. If the Assessment finds no significant environmental impacts, and if there are no objections, the Corps may issue a permit within 30 days after the close of public notice. If objections are raised the applicant may rebut. If the Assessment finds that the project may result in significant environmental affects, the Corps may require an Environmental Impact Statement, holding public hearings to gather additional information. After the environmental issues and/or objections have been resolved, if the permit is found to be in the public interest, it i issued upon payment of the appropriate fee.

Fees:

$\$ 100$

Other Information: 
Issuing Agency: Commander OAN

Eleventh Coast Guard District

501 West Ocean Blvd.

Long Beach, CA 90822

(310) $980-4300$ ext. 501

Statutory Reference:

Regulatory Reference: Part 66, Title 33, Code of Federal Regs.

Activities Covered: Placing aids to navigation in navigable waters.

Process: $\quad$ Applicant completes and files Form USCG 2554. Private Aids to Navigation Application. Coast Guard reviews application and establishes requirements.

Fees: $\quad$ None

Other Information:

3. AQUACULTURE REGISTRATION

Issuing Agency: Department of Fish and Game

1416 Ninth Street

Sacramento, CA 95814

(916)653-6194 FAX (916)653-8256

Statutory Reference: Sec. 15101, California Fish and Game Code.

Regulatory Reference: Sec. 235, Title 14, Calif. Code of Reg.

Activities Covered: Aquaculture operations

Process: $\quad$ Application describing facility location, design and species to be cultivated is reviewed by regional biologist(s). Site visit, if necessary.

Fees:

$\$ 400$ for new application, $\$ 200 /$ year annual renewal plus $\$ 300$ /year annual surcharge for operations with gross sales greater than $\$ 25,000 /$ year.

Other Information:

4. IMPORTATION PERMIT

Issuing Agency: Department of Fish and Game

1416 Ninth Street

Sacramento, CA 95814 
(916)653-6194 FAX (916)653-8256

Statutory Reference: Sec. 15600, California F\&G Code

Regulatory Reference: Sec. 236, Title 14, CCr

Activities Covered: Importation of live aquatic plants and animals.

Process: $\quad$ Application describing species, origin, and destination is reviewed by fisheries biologist, disease certifications are verified, disease inspections scheduled, valid permit required prior to importation.

Fees:

$\$ 34.50$ plus cost of inspection

Other Information:

5. WILD BROODSTOCK COLLECTION PERMIT

Issuing Agency: Department of Fish and Game

1416 Ninth Street

Sacramento, CA 95814

(916)653-6194 FAX (916)653-8256

Statutory Reference: $\quad$ Sec. 5503 and 15300. F\&G Code

Regulatory Reference: Sec. 243, Title 14, CCR

Activities Covered: Collection of wild aquatic stock for use in developing broodstock.

Process: $\quad$ Application describing species, location and method of collection is reviewed by fishery biologist. Permits for white sturgeon or striped bass collection require special authorization from the Fish and Game Commission.

Applicants for white sturgeon permits must obtain approval of broodstock development plan. Striped bass collections require presence of DFG observer.

Fees: $\quad \$ 34.50$ plus any necessary DFG expenses. Fee for white sturgeon or striped bass permit is $\$ 500$. Striped bass observer fee is $\$ 280 /$ day.

Other Information: Terms of collection normally require return of collected stock to wild after spawning and stocking of mitigation fish. 
Issuing Agency: Department of Fish and Game

1416 Ninth Street

Sacramento, CA 95814

(916)653-6194 FAX (916)653-8256

Statutory Reference: Sections 1600-1607, F\&G Code

Regulatory Reference:

Activities Covered: Lake and Streambed Alteration/Diversion

Process: $\quad$ Lake/Streambed Alteration Agreement negotiated to avoid or mitigate any adverse impacts to fish and wildlife resources caused by project.

Fees:

Range from $\$ 132$ to $\$ 1191$ and depend on project impacts and development cost of project (cost categories are $<\$ 25,000$, $\$ 25,000=500,000$, and $>\$ 500,000)$. Fee may be required annually.

Other Information:

\section{STATE WATER BOTTOM LEASE}

Issuing Agency: Department of Fish and Game

1416 Ninth Street

Sacramento, CA 95814

(916)653-6194 FAX (916)653-8256

Statutory Reference: Sections 15400-15415, F\&G Code

Regulatory Reference: Sec. 237, Title 14, CCR

Activities Covered: $\quad$ Aquaculture on, or over, State owned tidal or subtidal ocean water bottoms.

Process:

Application describing location and methods reviewed by DFG, State Lands Commission, and Department of Health Services. Recommendation by DFG to F \& G Commission as part of public hearing process. Commission grants lease, requires annual proof of use or lease declared abandoned.

Fees:

Application fee $\$ 500$. Plus, annual rent by competitive bid or minimum of $\$ 2$ /acre for leases over 10 acres, $\$ 10 /$ acre if 10 acres or less. Plus, tax on production not to exceed landing tax rates for wild harvest. 
Other Information:

\section{STATE LAND LEASE} Issuing Agency:

State Lands Commission

100 Howe Avenue \#100

Sacramento, CA 95825

(916)574-1893 FAX (916)574-1885

Statutory Reference: Section 6501, Public Resources Code

Regulatory Reference:

Activities Covered: Lease of right of way across State submerged lands and beaches for ocean intake and discharge pipes for onshore aquaculture facilities.

Process:

Application from project sponsor reviewed by Commission staff includes determination of appropriate level of environmental documentation that will be required. After environmental documents are circulated, a public hearing is held and the Commission makes a determination whether or not to issue the lease.

Fees:

Application fee of $\$ 1750$ plus $\$ 25$ filing fee. Annual rent is based on $9 \%$ of appraised value of the leased lands or $\$ .02 /$ dia. inch/linear foot, with a minimum rent of $\$ 100$.

Other Information: Term of lease up to 20 years.

\section{SHELLFISH HANDLING AND MARKETING CERTIFICATE} Issuing Agency: Department Of Health Services Food and Drug Branch 601 N. 7th Street P.O. Box 942732

Sacramento, CA $94234-7320$

(916)445-2263 FAX (916)322-6326

Statutory Reference: $\quad$ Sec.28500-28519.5, Health and Safety Code

Regulatory Reference: Sections 7707-7762, Title 17, CCR

Activities Covered: Facilities, equipment, handling, shucking, storing, packaging and shipping of shellfish after harvest.

Process:

Application reviewed by DHS, plant inspected (periodic unannounced inspections during operation), packing \& 
shipping requirements described. Preapproval required for on-shore wet storage, depuration facilities and processes.

Fees: $\quad$ None

Other Information: California program conforms to National Shellfish Sanitation Program guidelines

10. SHELLFISH GROWING AREA CERTIFICATE

Issuing Agency: Department of Health Services

Environmental Management Branch

601 N. 7th Street

P.O. Box 942732

Sacramento, CA $94234-7320$

(916)324-2205 FAX (916)323-9869

Statutory Reference: $\quad$ Sections 28500-28508, 28516-28519.5, Health and Safety Code

Regulatory Reference: Sections 7706-7733, Title 17, CCR

Activities Covered: Cultivation and harvesting of bivalve shellfish for sale for human consumption.

Process: $\quad$ Application reviewed by DHS to assure that growing water meets standards of cleanliness. Water samples analyzed, watershed evaluated, on-going water-quality data required.

Fees: $\quad$ None

Other Information: California program conforms to National Shellfish Sanitation Program guidelines.

11. COASTAL DEVELOPMENT PERMIT

Issuing Agency: California Coastal Commission

45 Fremont St., Suite 2000

San Francisco, CA 94105

(415)904-5200 FAX (415)904-5400

Statutory Reference:

Regulatory Reference:

Activities Covered: Project Approval for development within the coastal zone.

Process:

Application reviewed by Commission staff for

recommendation at public hearing to Commission which also 
hears testimony of applicant and other concerned parties. If the Commission has previously certified a local coastal program, a local government has the authority to issue permits within the onshore jurisdiction. Decisions of local governments may be appealed to the Commission.

Fees:

Dependent on project, range from $\$ 200$ to $\$ 2000$. Fee for aquaculture projects with development costs less than $\$ 100,000$ are most often $\$ 600$.

Other Information:

12. WEIGHMASTER LICENSE

Issuing Agency: Department of Food and Agriculture

Division of Measurement Standards

8500 Fruitridge Road

Sacramento, CA 95826

(916)229-3000 FAX (916)229-3026

Statutory Reference: Sections 12700-12736, Business and Professions Code

Regulatory Reference:

Activities Covered: Weighing, measuring, or counting any commodity and issuing a statement used as the basis for either the purchase or sale of that commodity or charge for service.

Process: $\quad$ License issued upon application and payment of fees. Form (Certificates) for use prescribed, and maintenance of records required. License renewed annually.

Fees:

$\$ 75 / \mathrm{yr}$ for fixed location, $\$ 30 / \mathrm{yr}$ for each additional fixed location, $\$ 200 / \mathrm{yr}$ if location not fixed, $\$ 20 / \mathrm{yr}$ for each deputy weighmaster.

Other Information: Use of displacement method for weighing live fish is permitted.

13. WASTE DISCHARGE REQUIREMENTS (WDR)

Issuing Agency: Regional Water Quality Control Boards

(916)657-2390 FAX (916)657-2388

Statutory Reference: Sections 13260-13272, California Water Code

Regulatory Reference: Sec. 2200-2235.4, Title 23, CCR 
Activities Covered: Discharge of Waste which may affect groundwater quality

Process:

Fees:

Other Information:
Applicant files a complete "Report of Waste Discharge" with the appropriate Regional Board at least 120 days before discharging waste. Report evaluated by the Regional Board staff to determine whether the discharge is consistent with adopted water quality standards. At a public meeting, Board sets limits on the discharge as a condition of approval.

Annual fees dependant on type and volume of discharge. Range from $\$ 200$ to $\$ 10,000$.

The need for Waste Discharge Requirements may be waived by the Regional Board based on site-specific factors.

14. NATIONAL POLLUTANT DISCHARGE ELIMINATION SYSTEM(NPDES)

Issuing Agency: Regional Water Quality Control Boards

(916)657-2390 FAX (916)657-2388

Statutory Reference: Sections 13260-13272, California Water Code Sections 318 and 402, Federal, Pollution Control Act, as Amended by the Clean water Act of 1977

Regulatory Reference: Sec. 2200-2235.4, Title 23, CCR

Sec. 122.224-125.3, Code of Federal Regulations.

Activities Covered: Discharge of waste to surface waters.

Process: $\quad$ File a complete "Report of Waste Discharge" with the appropriate Regional Board at least 180 days before discharge. Board forwards report to Regional Administrator of the federal EPA for review and comment. Board staff prepares tentative permit for review and comment by EPA. At a public meeting, Board adopts or modifies permit. If, within 10 days, EPA objects, the permit does not become effective until the State Water Resources Control Board satisfies all objections.

Fees: $\quad$ Annual - depend on type and volume of discharge. Range: $\$ 200$ to $\$ 10,000$.

Other Information: NPDES Permit may be waived by the Regional Board based on site-specific factors.

15. PERMIT TO APPROPRIATE WATER

Issuing Agency: State Water Resources Control Board

Division of Water Rights 
P.O. Box 2000

Sacramento, CA 95810

(916)322-4503

Statutory Reference: Sections 1200 through 1851, Part 2 of Division 2, California Water Code

Regulatory Reference: Sections 650 through 860, Subchapter 2, Title 23, CCR.

Activities Covered: Diversion of water from a surface stream or other body of water for use on non-riparian land; to store unappropriated surface water seasonally; direct use of water which would not be naturally in the source (ie. agricultural return waters); to divert groundwater flowing in a known and definite subterranean channel.

Process:

Submit "Application to Appropriate Unappropriated Water"

Fees:

Depends on rate or amount of water requested: minimum $\$ 100$ filing fee and $\$ 100$ permit fee. An environmental processing fee of $\$ 850$ by Dept. of Fish and Game.

Other Information:

16.

STATEMENT OF WATER DIVERSION AND USE

Issuing Agency: State Water Resources Control Board

Division of Water Rights

P.O. Box 2000

Sacramento, CA 95810

(916)322-4503

Statutory Reference: Sections 5100 through 5108, Part 5.1 of Division 2, California Water Code.

Regulatory Reference: None

Activities Covered: Diversion of water under a riparian claim and appropriations initiated prior to December 19, 1914.

Process:

Water users submit "Statement of Water Diversion and Use". Every three years, supplemental statements reiterating name and address of the user, owner of the property the water is used on, and the name of the stream and amount of water taken from it are filed. Division of Water Rights assigns an identification number to the Statement and returns one copy to the water user. 
Fees:

None

Other Information:

17. MIGRATORY BIRD DEPREDATION PERMIT

Issuing Agency: U.S. Fish and Wildlife Service

Migratory Bird Office - MBHF

911 N.E. 11th Ave.

Portland, OR 97232-4181

(503)872-2715 FAX (503)231-2364

Statutory Reference: Migratory Bird Treaty Act

Regulatory Reference: Parts 13 and 21, Title 50, CFR

Activities Covered: Using lethal control methods on migratory birds, as limited by each permit, which are causing aquaculture crop losses.

Process:

Application is investigated by local USDA, APHIS-ADC biologist. ADC documents losses at the farm and makes a recommendation to USFWS on the types and numbers of birds for permit. USFWS reviews the recommendations and makes a determination whether or not to issue the permit, and of the types and numbers of birds to include. A copy of each permit is made available to California DFG following issuance.

Fees: $\quad \$ 25$

Other Information: 


\section{COLORADO}

1. COLORADO AQUACULTURE PERMTT

Issuing Agency: Department of Agriculture/Markets Division

700 Kipling St. Suite 4000

Lakewood, CO 80215

(303)239-4114 FAX (303) 239-4125

Statutory Reference: $\quad 35-24.5-101$

Regulatory Reference:

Activities Covered: Propagation and culturing of aquatic species.

Process: $\quad$ Application must be submitted to the Department of Agriculture.

Fees: $\quad \$ 150$ annually

Other Information:

2. PERMIT TO CONSTRUCT A WELL

Issuing Agency: Division of Water Resources

1313 Sherman $\mathrm{Rm} 818$

Denver, CO 80203

(303)866-3581 FAX (303)866-3589

Statutory Reference: Sections 37-90-107 and 137, CRS

Regulatory Reference: $\quad 2$ CCR 410-1, 2 CCR 402-4

Activities Covered: Diversion and beneficial use of underground water and well construction.

Process: $\quad$ Submit application for evaluation (in some cases publication is required). If proposal complies with the statutes and no other water rights are injured a permit is granted. If the permit is denied it may be appealed as provided by law.

Fees: $\quad \$ 60$ filing fee

Other Information: This permit would be required only if underground water was to be used or exposed for the operation. A water right may also be required.

3. WATER RIGHTS APPROVAL 
Issuing Agency: State Water Courts

Statutory Reference: Section 37-92-101 CRS

Regulatory Reference:

Activities Covered: Determination and Administration of water rights.

Process: $\quad$ Application to Water Court, publication for objections, ruling of referee, hearing if needed, Water Court Judge decision on the water rights and its priority

Fees:

Yes (varies)

Other Information: The Division of Water Resources (State Engineer) is responsible for administration of water rights under the priority system. 


\section{IDAHO}

1. NATIONAL POLLUTANT DISCHARGE ELIMINATION SYSTEM PERMIT Issuing Agency: Environmental Protection Agency

Chief Water Permits Section Reg. 10

Park Place Building 13th floor

1200 6th Avenue WA134

Seattle, WA 98101

(206)553-1389

Statutory Reference: Clean Water Act

Regulatory Reference:

Activities Covered: Discharge of fish farm effluent into waters of the U.S.

Process: $\quad$ Application made to EPA. On-site visit, draft permit, advertise and hold hearing, issue permit.

Fees:

Other Information: EPA has not issued some NPDES permits because of inability to complete process.

\section{WATER QUALITY CERTIFICATION}

Issuing Agency: $\quad$ Department of Environmental Quality

1410 N. Hilton 3rd floor

Boise, ID 83720

Statutory Reference: $\quad$ Sect 401 of Clean Water Act and State Water Quality

Standards

Regulatory Reference:

Activities Covered: Certification of fish farms so they can receive NPDES Permit.

Process: $\quad$ Application

Fees:

Other Information:

3. WATER APPROPRIATION AND USE WATER RIGHTS

Issuing Agency: Department Water Resources

1301 N. Orchard

Boise, ID 83706-2237 
(208)327-7900

Statutory Reference:

Regulatory Reference:

Activities Covered: Permit to put water to beneficial use

Process: $\quad$ Application and review

Fees: $\quad$ Yes

Other Information:

4. COMMERCIAL FISH FACILITY LICENSE

Issuing Agency: Department of Agriculture

Bureau of Animal Health

P.O. Box 7249

Boise, ID 83720

(208)334-3256 FAX (208)334-2170

Statutory Reference: Chap. 46 Idaho Code

Regulatory Reference:

Activities Covered: Obtain, possess, preserve, or propagate fish for sale.

Process:

Application

Fees:

$\$ 25$ per facility

Other Information: 


\section{MONTANA}

1. IMPORT PERMIT (87-5-701 - 87-5-721)

FISH DISEASE CERTIFICATION (87-3-209 - 87-3-227)

Issuing Agency: Department of Fish, Wildlife, \& Parks

Fish, Wildlife, \& Parks Building

1420 East Sixth Ave.

Helena, MT 59629-0701

(406)444-5686

Statutory Reference: $\quad$ 87-3-209 thru 87-3-227

Regulatory Reference: Code of Montana Regulations Annotated

Activities Covered: Fish disease, designated pathogens considered dangerous, permit procedures

Process: $\quad$ Outlined in Administrative Rules of Montana 12-7-501 thru 12-7-507; 12-5-505 outlines permit application/procedures.

Fees: $\quad$ None

Other Information:

2. COMMERCIAL FISH POND LICENSE

Issuing Agency: Department of Fish, Wildlife, \& Parks

Fish, Wildlife, \& Parks Building

1420 East Sixth Ave.

Helena, MT 59629-0701

(406)444-5686

Statutory Reference: $\quad 87-4-603$ thru 87-4-607

Regulatory Reference: Code of Montana Regulations Annotated

Activities Covered:

Process: Submit request to above department.

Fees: $\quad$ Initial permit free of charge; $\$ 500$ surety bond to ensure fish are not sold or spawned from any public waters or violate conditions of license.

Other Information:

3. FEDERAL RIVERS AND HARBORS ACT (FORM \#4345) 
Issuing Agency:

Western Montana:

U.S. Army Corp of Engineers

1520 East Sixth Ave.

Helena, MT 59620

(406)444-6670

Eastern Montana:

U.S. Army Corps of Engineers

Regulatory Office, Room 218

Federal Building and Post Office

2602 1st Avenue North

Billings, MT 59101

(406)657-6891

Statutory Reference:

Regulatory Reference:

Activities Covered: The construction of any structure in or over any navigable water of the United States, the excavation from or depositing of material in such waters, or the accomplishment of any other work affecting the course, location, condition, or capacity of such waters. Navigable waters in Montana are the Missouri River from Three Forks downstream to the Montana-North Dakota border, the Yellowstone river from the Canadian border downstream to Jennings, Montana.

Process:

Applications submitted to appropriate Corps of Engineers' office for review. Project approval may take 60-90 days.

Fees:

Varies from $\$ 10$ for private individuals to $\$ 100$ for commercial applicants.

Other Information:

4. FEDERAL REGISTER; TITLE 50

Issuing Agency: Department of Fish, Wildlife, \& Parks

Fish, Wildlife, \& Parks Building

1420 East Sixth Ave.

Helena, MT 59629-0701

(406)444-5686

Statutory Reference: CFR Title 50

Regulatory Reference: 
Activities Covered: Collection and interstate transport of wildlife and fish.

Process:

State/ territory laws and regulations pertaining to collection of wildlife and fish may be further enforced through the Federal Title 50 Lacy Act.

Fees:

Other Information: Violations of State statues which may be considered a misdemeanor offense can become a felony under Federal law.

\section{CERTIFICATE OF WATER RIGHT (MONTANA WATER USE ACT) \\ Issuing Agency: Water Rights Bureau \\ Department of Natural Resources \& Conservation \\ 1520 E. Sixth Ave. \\ Helena, MT 59620 \\ (406)444-6610}

Statutory Reference: $\quad$ 85-2-301-852-308

Regulatory Reference: Code of Montana Regulations Annotated

Activities Covered: Beneficial water use permit before commencing to construct new or additional diversion, withdrawal, impoundment, or distribution works for any surface water or groundwater of 100 gallons per minute or more.

Process: Water right application forms are available at all 56 County Clerk and Recorder's office and at the nine Water Rights Field Offices located in Miles City, Billings, Bozeman, Helena, Glasgow, Lewistown, Missoula, Kalispell, and Havre.

Fees:

Filing fee plus $\$ 1$ per acre - foot of ground water appropriated. Application fees range from $\$ 50$ to $\$ 250$, depending on the volume of water requested for appropriation, and whether the use is consumptive or nonconsumptive.

Other Information:

6. STREAM BED AND LAND PRESERVATION ACT PERMIT Issuing Agency: Department of Natural Resources \& Conservation 1520 E. Sixth Ave.

Helena, MT 59620

(406)444-6667 
Statutory Reference: $\quad 310$ Permit

Regulatory Reference:

Activities Covered: Any activity that physically alters or modifies the bed and banks of a stream.

Process:

Contact the conservation district office to obtain a permit application prior to any activity in or near a stream. After submission of an application to the conservation district office, district supervisors must determine within five days of their monthly meeting if the proposed activity requires a 310 permit. If a permit is required, a team composed of a district supervisor; a Department of Fish, Wildlife and Parks biologist; and the landowner conduct a site inspection. The supervisors have 60 days from the date of application to approve or deny the permit.

Fees: $\quad$ None

Other Information:

7. STATE POLLUTANT DISCHARGE ELIMINATION SYSTEM

Issuing Agency: Water Quality Bureau

Department of Health \& Environmental Sciences

A-206 Cogswell Building

Helena, MT 59620

(406) 444-2406

Statutory Reference: $\quad 75-5-401-75-5-402$

Regulatory Reference: Code of Montana Regulations Annotated

Activities Covered: Applies to all discharge to surface or groundwater, including construction dewatering discharges and placer mining.

Process: $\quad$ Contact above department.

Fees:

Other Information: Permit applies to certain locations and activities only.

8. STREAM PROTECTION ACT PERMIT

Issuing Agency: Habitat Protection Bureau

Fisheries Division

Department of Fish, Wildlife and Parks 
1420 East Sixth Avenue

Helena, MT 59620

(406)444-2449

Statutory Reference:

Regulatory Reference:

Activities Covered: Any project including the construction of new facilities or the modification, operation, and maintenance of an existing facility which may affect the natural existing shape and form of any stream or its banks or tributaries.

Process: $\quad$ Anyone planning a project must submit a Notice of Construction (application) to the Dept. of Fish, Wildlife and Parks, which has up to 60 days to review the application, perform an on-site investigation, and approve, modify, or deny the application.

Fees: $\quad$ None

Other Information:

9. FLOODPLAIN AND FLOODWAY MANAGEMENT ACT (FLOODPLAIN DEVELOPMENT PERMIT)

Issuing Agency: $\quad$ Floodplain Management Section

Department of Natural Resources \& Conservation 1520 E. Sixth Ave.

Helena, MT 59620

(406)444-6667

Statutory Reference:

Regulatory Reference:

Activities Covered: New construction including, but not limited to, placement of fill, roads, bridges, culverts, transmission lines, irrigation facilities, storage of equipment or materials, excavation, and new construction of or additions to mobile homes and residential and commercial buildings.

Process:

Permit applications are available from the local floodplain coordinator or from the Department of Natural Resources and Conservation. 
Fees:

Application fees are established by the local government and vary widely throughout the state.

Other Information:

10. SHORT-TERM EXEMPTION FROM MONTANA'S SURFACE WATER QUALITY STANDARDS (3A AUTHORIZATION)

Issuing Agency: Water Quality Bureau

Department of Health and Environmental Sciences

A-206 Cogswell Building

Helena, MT 59620

(406)444-2406

Statutory Reference:

Regulatory Reference:

Activities Covered: Any activity in any state water that will cause unavoidable violations of water quality standards.

Process:

A 3A Authorization must be obtained prior to initiating a project. The Authorization may be obtained from the Water Quality Bureau, or may be waived by the Department of Fish, Wildlife and Parks during its review process under the Natural Streambed and Land Preservation Act (310 permit) or the Stream Protection Act (124 permit). Individual applications submitted to the Water Quality Bureau are normally processed within 14 days. Authorizations waived under the 310 or 124 permit process correspond to the time frame under each permit system, usually 30 - 60 days.

Fees:

None

Other Information:

11. LAND-USE LICENSE OR EASEMENT ON NAVIGABLE WATERS

Issuing Agency: Department of State Lands

Surface Management Bureau

1625 Eleventh Avenue

Helena, MT 59620

(406)444-2074

Statutory Reference:

Regulatory Reference: 
Activities Covered: The construction or placement of a structure or improvement on lands below the low water mark of navigable streams. Customary and historic maintenance and repair of existing irrigation facilities or activities that do not alter, modify, or change the existing shape or impact the potential navigability of the waterway are exempt.

Process:

A DSL land use or easement application must be submitted to the appropriate Area Land Office. The Area Office staff will review the application, conduct a field investigation if necessary, and file an environmental action checklist. A written report and recommendation is then submitted to the Resource Development Bureau in Helena, which makes the final determination and recommends stipulations as necessary.

Fees:

A Land-Use license can be approved and issued within 14 days upon payment of the $\$ 25$ application fee and the onetime rental of $\$ 100$ per acre. The license may be held for a maximum period of 20 years, with the ability to renew for an additional 20 years with the payment of just the $\$ 25$ application fee. An easement requires approval from the Board of Land Commissioners which may take up to 45 days. The easement application fee is $\$ 50$ with an additional easement rental that varies based upon the appraised value of the property.

Other Information:

12. FEDERAL CLEAN WATER ACT (404 PERMIT)

Issuing Agency: Western Montana:

U.S. Army Corp of Engineers

1520 East Sixth Ave.

Helena, MT 59620

(406)444-6670

Eastern Montana:

U.S. Army Corps of Engineers

Regulatory Office, Room 218

Federal Building and Post Office

26021st Avenue North

Billings, MT 59101

(406)657-6891

Statutory Reference: 
Regulatory Reference:

Activities Covered: Any activity that will result in the discharge of dredged or placement of fill material into waters of the United States, including their adjacent wetlands.

Process:

Submit application to appropriate Corps regulatory office for review. Permit authorization varies depending on size and scope of project. Activities that meet the conditions for a Nationwide Permit may be approved in a week or less by the state Corps office. Individual and General permits are processed individually and require a public review period. Permit approval may take 60 to 90 days.

Fees:

Vary from $\$ 10$ private individuals to $\$ 100$ commercial.

Other Information: OTHER LAWS THAT MAY APPLY, DEPENDING UPON LOCATION AND ACTIVITY.

- Shoreline Protection Act

- Lakeshore Protection Act

- General Mining Laws/Small Miner's Placer and Dredge Operations

- County Building and Septic System Installation Codes And Regulations 


\section{NEVADA}

1. TRIPLOID GRASS CARP USE PERMIT

Issuing Agency: Division of Wildlife

P.O. Box 10678

Reno, NV 89520

(702)688-1500 FAX (702)688-1595

Statutory Reference: $\quad$ NRS 503.597, 501.379, 503.590, 504.245, 504.295

Regulatory Reference: Chapters 503 and 504 of the Nevada Administrative Code

Activities Covered: $\quad$ Possession of Triploid Grass Carp.

Process: $\quad$ Application, review, Memorandum of Understanding, Issuance of permit for Certified Triploid fish only.

Fees:

None

Other Information: Fish used for aquatic vegetation control in Golf Course ponds and private ponds.

2. COMMERCIAL WILDLIFE CULTURING FACILITY

Issuing Agency:

Division of Wildlife

P.O. Box 10678

Reno, NV 89520

(702)688-1500 FAX (702)688-1595

Statutory Reference: $\quad$ NRS 504.295, 502.240, 504.245, 501.379, 501.381, 503.590, 503.597

Regulatory Reference: Chapters 503 and 504 of the Nevada Administrative Code

Activities Coyered: For the propagation, culture, maintenance and commercial sale of gamefish and other aquatic life excluding aquatic plants.

Process:

Permittee submits application; proposal and facility are evaluated; permit is issued.

Fees:

$\$ 100$, renewable annually

Other Information: Little commercial activity in Nevada due to limited water resources. 
Issuing Agency: $\quad$ Division of Wildlife

P.O. Box 10678

Reno, NV 89520

(702)688-1500 FAX (702)688-1595

Statutory Reference: $\quad$ NRS 503.597

Regulatory Reference: $\quad$ NAC 503.110 thru 503.140, inclusive; 503.515; 503.530; 503.535 .

Activities Covered: Issued to persons who wish to receive, bring or have brought or shipped into State of Nevada any aquatic life, wildlife, spawn, etc.

Process:

Applicant submits application, Department evaluates and issues or denies.

Fees:

$\$ 5$ - good for multiple shipments if the same species from the same point of origin and to the same destination.

Other Information:

4. NON - COMMERCIAL CULTURING FACILITY

Issuing Agency: Division of Wildlife

P.O. Box 10678

Reno, NV 89520

(702)688-1500 FAX (702)688-1595

Statutory Reference: $\quad$ NRS 504.295, 502.240, 501.379, 501.381, 503.590, 503.597, 504.245

Regulatory Reference: Chapters 503 and 504 of Nevada Administrative Code

Activities Covered: Private individual culturing aquatic animal species (other than aquaria) and does not sell fish commercially. For the possession, cultivation, and propagation of wildlife.

Process: $\quad$ Submit application; Division evaluation - issuance.

Fees: $\quad \$ 5$ renewable annually

Other Information: These permits are issued mostly to individuals who wish to keep live game fish in their possession in backyard ponds.

\section{EFFLUENT DISCHARGE PERMIT}

Issuing Agency: Division of Environmental Protection

Capitol Complex 
333 W. Nye Lane

Carson City, NV 89710

(702)687-4670 FAX (702)885-0868

Statutory Reference: $\quad$ NRS Chapter 445 - Nevada Water Pollution Control Law

Regulatory Reference:

Activities Covered: Authorizes facility discharge into waters of the State.

Process: $\quad$ Application, review, public notice, issuance of permit.

Fees: $\quad$ Depends on number of discharge points and quantity.

Other Information: Requires periodic monitoring and sampling. 


\section{NEW MEXICO}

No permits impacting the aquaculture industry due to the fact that "The State of $\mathrm{Ne}$ Mexico does not have an aquaculture industry". 
OREGON

\begin{tabular}{ll} 
1. VARIOUS AQUACULTURE/MARICULTURE PERMTTS \\
\hline Issuing Agency: & Department of Fish \& Wildlife \\
& 2501 SW First Avenue \\
& Portland, OH 97207 \\
(503)229-5403
\end{tabular}

Department of Environment Quality

Water Quality Control Division

811 SW Sixth Avenue

Portland, OR 97204

(503)229-5279

Department of Agriculture

Natural Resources Division

635 Capitol St. NE

Salem, OR 97310

(503)378-3810 FAX (503)378-2590

Department of Water Resources

3850 Portland Road, NE

Salem, OR 97310

(503)378-3741 FAX (503)378-8130

Division of State Lands

775 Summer Street

Salem, OR 97310

(503)378-3805 FAX (503)378-4844

Other Information:

There are numerous overlapping permits and State government regulatory permits for the kinds of aquaculture permitted in Oregon. Apply first at Oregon Department of Fish and Wildlife to get started. 


\section{UTAH}

In the process of writing regulations. 


\title{
WASHINGTON
}

\author{
1. WATER QUALITY CERTIFICATION \\ Issuing Agency: Department of Ecology \\ Sediments Environmental Review Section \\ P.O. Box 47600 \\ Olympia, WA $98504-7600$ \\ (206)493-2932 FAX (206)493-2967
}

Statutory Reference: Section 401 Clean Water Act

Regulatory Reference: WAC 173-225

Activities Covered: In-water construction that involves discharge of pollutants and needs a Corps permit.

Process:

Apply for federal permit, Dept. of Ecology is then notified. If additional information is needed, Dept. of Ecology contacts applicant. If acceptable, approval or conditional certification is issued.

Fees: $\quad$ No charge

Other Information: Penalty: Federal permit not issued.

2. WATER QUALITY STANDARDS MODIFICATION

Issuing Agency: Department of Ecology

Water Quality Program

P.O. Box 47600

Olympia, WA $98504-7600$

(206)438-7490 FAX (206)438-7490

Statutory Reference: $\quad$ RCW 90.48

Regulatory Reference: WAC 173-201

Activities Covered: Discharge of pollutants causing water quality below standard.

Process:

Applicant applies to Dept. of Ecology.

Fee:

No charge

Other Information: Penalty: Willful violation = crime punishable by a fine of up to $\$ 10,000$ and/or imprisonment for not more than a year (violation $=$ ea. day). resource damage $=$ liability to pay damages to replenish such resource. Civil penalty of up to $\$ 10,000$ per violation. 
3.

NAVIGATIONAL MARKINGS

Issuing Agency:

U.S. Coast Guard

Commander (OAN) 13th Coast Guard District

Federal Bldg., 915 2nd Ave.

Seattle, WA 98174-1067

(206)553-5864 FAX(206)553-5866

Statutory Reference: $\quad 14$ USC 85

Regulatory Reference:

Activities Covered: Fixed or floating structures in or over water.

Process:

Fees:

No charge

Other Information: Penalty: Misdemeanor (up to $\$ 100$ per day).

4. FEDERAL DREDGE AND FILL PERMITS-SUBSECTION 10 OF THE RIVERS AND

HARBOR ACT; SUBSECTION 404 OF THE CLEAN WATER ACT-_(CONSOLIDATED

PERMIT)

Issuing Agency:

Army Corps of Engineers

CENPS-OP-RG, Regulatory Branch

4735 E. Marginal Way South

Seattle, WA $98134-2385$

(206)764-3495 FAX (206)764-6602

Statutory Reference: Section 10 (33 USC 403; Section 404 (33 USC 1344)

Regulatory Reference:

Activities Covered: $\quad$ Placement of structures, excavation, deposit of dredge or fill material into navigable waters.

Process:

Apply to the Army Corps of Engineers. Explain project, include site drawings $(8-1 / 2 \times 11)$ of proposed work, quantities of fill and amount of dredge. Corps evaluates and solicits comments from numerous federal and state agencies. Corps evaluates environmental and navigational impacts and generally, waits for state permits and certification before issuing permit.

Fees:

No fee for government entities; for individual $\$ 10$; for commercial $\$ 100$. 
Other Information: $\quad$ Penalty: Civil: up to $\$ 10,000$ per day. Criminal: $\$ 2,500$ $\$ 25,000$ per day for willful or negligent violation (and/or 1 year imprisonment).

5. FISH DISEASE CONTROL

Issuing Agency: Department of Fisheries (develop jointly with Agriculture)

Hatchery Management Division

P.O. Box 43154

Olympia, WA 98504-3154

(206)902-2658 FAX (206)902-2943

Statutory Reference: $\quad$ RCW 75.58

Regulatory Reference:

Activities Covered:

Process:

Fees:

No charge

Other Information: Penalty: Unless emergency, enforcement after opportunity for hearing.

6. REGISTRATION OF AQUATIC FARMERS

Issuing Agency: Department of Fisheries

Licensing Division

P.O. Box 43141

Olympia, WA $98504-3141$

(206)902-2488 FAX (206)902-2942

Statutory Reference: $\quad$ RCW 75.58

Regulatory Reference: WAC 220-76

Activities Covered: The cultivation of private sector aquatic products.

Process: $\quad$ Apply to Dept. of Fisheries. (Name, contact person, DSHS, shellfish certification number, species, method, site location and site drawing.

Fees:

No charge

Other Information:

7. AQUACULTURE ID OF PRIVATE SECTOR PRODUCTS Issuing Agency: Department of Agriculture 
Market Development Division

P.O. Box 42560

Olympia, WA 98504-2560

(206)902-1932 FAX (206)902-2089

Statutory Reference: $\quad$ RCW 15.85

Regulatory Reference:

Activities Covered: $\quad$ Products cultivated by aquatic farmers which otherwise would be regulated by Fisheries or Wildlife.

Process:

Follow regulations for labeling or sale documentation.

Fees:

No charge

Other Information:

8. NATIONAL POLLUTANT DISCHARGE ELIMINATION SYSTEM (NPDES) PERMIT Issuing Agency:

Department of Ecology

Water Quality Program

P.O. Box 47600

Olympia, WA 98504-7600

(206)438-7490 FAX (206)438-7490

Statutory Reference: 33 USC 1328; RCW 90.48

Regulatory Reference:

Activities Covered: Any person who conducts a commercial or industrial operation which results in the disposal of solid or liquid waste materials into the water of the State.

Process: - Apply to the Department of Ecology

Fees:

$\$ 750$ for set up of new permit; $\$ 3,405 / y r$. annual fee.

Other Information: Penalty: Willful violation - crime punishable by a fine of up to $\$ 10,000$ and/or imprisonment for not more than a year (each day is a violation). Resource damage - liability to pay damages to replenish such resource. Civil penalty of up to $\$ 10,000$ per violation.

9. HYDRAULIC PROIECT APPROVAL

Issuing Agency: Department of Fisheries (WDF)

Habitat Management Div.

P.O. Box 43155 
Olympia, WA $98504-3155$

(206)902-2534 FAX (206)902-2946

Department of Wildlife (WDW)

Habitat Management Div.

600 Capitol Way North

Olympia, WA 98501-1091

(206)753-3318 FAX (206)586-0248

Statutory Reference: $\quad$ RCW 75.20.100

Regulatory Reference:

Activities Covered: $\quad$ Any project that will use, divert, obstruct or change the natural flow or bed of any of the salt or fresh waters of the state.

Process:

Apply to the responsible agency (Fisheries or Wildlife). Application shall contain general plans for the overall project, complete plans and specifications of the proposed construction subject to this chapter and complete plans for the protection of fish life. Forty-five day period to approve or deny.

Fees:

No charge

Other Information: Penalty: Civil penalty of up to $\$ 100$ per day. Criminal penalty-gross misdemeanor; continuation--declared a nuisance subject to abatement.

10. AQUATIC LAND LEASE

Issuing Agency: Department of Natural Resources

Aquatic lands Division

P.O. Box 47027

Olympia, WA $98504-7027$

(206)902-1100 FAX (206)902-1786

Statutory Reference: $\quad$ RCW 79.90.460(4) and 79.90.495

Regulatory Reference: $\quad$ WAC 332-30-161

Activities Covered: $\quad$ Any use of publicly owned aquatic lands (tidelands, beds of navigable waters or shorelands).

Process:

Complete application and submit with filing fee to DNR. Application must include description of land, Army Corps 
public notice number, shoreline substantial development permit number and SEPA checklist or DNS.

Fees:

Established through competitive bidding or negotiation.

Other Information: Penalty: Action in trespass.

\section{SHORELINE SUBSTANTIAL DEVELOPMENT \\ Issuing Agency: Association of Counties \\ 20610 th Avenue S.E. \\ Olympia, WA $98501-1311$ \\ (206)753-1886 FAX (206)753-2842}

Statutory Reference: $\quad$ RCW 90.58.140(2)

Regulatory Reference:

Activities Covered: Development in or on the water or on the shoreline, having a total cost or fair market value exceeding $\$ 2,500$.

Process:

If the Dept. of Ecology disagrees with the approval or denial, the DOE can appeal the local decision to the Shoreline Hearings Board. On either a conditional use permit or a variance under the Shoreline Management Act, the DOE may overrule a local decision. Conditional use permits are used for projects in unique situations as recognized in the Shoreline Master Program whereas variances are used in addressing project dimensional irregularities.

Fees:

No charge

Other Information: Penalty: Civil penalty not to exceed $\$ 1000$ per violation (or day). Willful violation - gross misdemeanor ( $\$ 25$ - \$1000 and/or 90 days). Third willful violation within 5 years - $\$ 500$ $-\$ 10,000$.

12. SHELLFISH CERTIFICATION

Issuing Agency: Department of Health

Office of Shellfish Programs

P.O. Box 47824

Olympia, WA $98504-7824$

(206)753-5994 FAX (206)586-4499

Statutory Reference: $\quad$ RCW 69.30

Regulatory Reference: 
Activities Covered: Sale of shellfish.

Process: $\quad$ Must be certified by DSHS.

Fees: $\quad$ Fees vary by type of operation and size.

Other Information: Penalty: Decertification and/or gross misdemeanor $\$ 25$ $\$ 1,000$ and/or 30 days.

13. STATEMENT OF CONSISTENCY WITH COASTAL ZONE MANAGEMENT ACT Issuing Agency: Department of Ecology

P.O. Box 47600

Olympia, WA $98504-7600$

(206)483-7062 FAX (206)438-7490

Statutory Reference: 16 USC 1456(c)

Regulatory Reference:

Activities Covered: Activities within the coastal zone.

Process:

This federal law has as an objective that each coastal state adopt a federally-approved coastal zone management program. The Shoreline Management Act has been certified as that program, therefore, the Dept. of Ecology reviews the local Shoreline Master Programs for the Area. If the Project is "consistent with the maximum extent practical" with the Coastal Zone Management Act, then the Dept. of Ecology will certify the project.

Fees: $\quad$ No charge

Other Information: Penalty: Civil penalty not to exceed $\$ 1000$ for each violation (or day). For willful violation--gross misdemeanor ( $\$ 25$ $\$ 1000$ and / or 90 days). Third willful violation within 3 years 


\section{WYOMING}

1. COMMERCIAL FISH HATCHERY LICENSE

Issuing Agency: Game and Fish Dept.

5400 Bishop Blvd.

Cheyenne, WY 82006

(307)777-4559 FAX (307)777-4610

Statutory Reference: $\quad$ WS 23-2-301, 23-4-102

Regulatory Reference: Wyoming Game and Fish Commission regulation for importation, possession, confinement, transportation, sale and disposition of live wildlife.

Activities Covered: Owning and operating fish hatchery or rearing unit for raising fish for resale.

Process:

Send fee and application to Wyoming Game and Fish Dept. Can request application from above address.

Fees:

$\$ 100$ per year plus $\$ 500$ Surety Bond

Other Information:

2. MINING PERMIT/LICENSE

Issuing Agency: Department of Environmental Quality - Land Quality

Division

122 W. 25th ST., 3rd Floor West

Cheyenne, WY 82002

(307)777-7756 FAX (307)634-0799

Statutory Reference: $\quad$ Environmental Quality Act W.S. 35-11-101 - W.S. 35-111428

Regulatory Ŕeference: Land Quality Division Rules and Regulations

Activities Covered: Removal of solid mineral from the earth for commercial purposes.

Process:

Contact the Division to determine what type of permit is required. The amount and detail of baseline operations and reclamation plan is dependant upon the size of the proposed operation.

Fees:

Permit: $\$ 100$ plus $\$ 10$ per each acre in the permit but not more than $\$ 2000$. License of $\$ 25$. 
Other Information: PUBLIC NOTICE IS REQUIRED FOR OPERATIONS LARGER THAN 10 ACRES.

\section{APPLICATION FOR PERMIT TO APPROPRIATE SURFACE WATER OR APPROPRIATE GROUND WATER \\ Issuing Agency: State Engineer's Office \\ Herschler Building, 4th Floor East \\ Cheyenne, Wyoming 82002 \\ (307)777-7354 FAX (307)777-5451}

Statutory Reference: W.S. 1977 41-3-101 to $41-3-938$

Regulatory Reference: State Engineer's Office Rules and Regulations

Activities Covered: Issuance of permits for all recognized beneficial uses of water, including aquaculture, when applied for in accordance with rules and regulations dependent there on.

Process: $\quad$ Upon proper application to the State Engineer (which includes a certified map) ${ }^{*}$. A permit is issued if the application is in compliance with the rules and regulations and in the best public interest. Once a permit is secured, construction may begin. Once facility is constructed and water is put to beneficial use, adjudication takes place.

Fees:

$\$ 25$

Other Information: $\quad$ * Certified mapping requirements.

For surface water source: file with application.

For ground water (well) source: file during adjudication process.

4. FOOD SAFETY (NO PERMIT REQUIRED)

Issuing Agency: Department of Agriculture/Consumer Health Services

2219 Carey Ave.

Cheyenne, WY 82002-0100

(307)777-6587 FAX (307)777-6593

Statutory Reference: W.S. 35-7-109-122

Regulatory Reference: 21 CFR Part 101 and 110 
Activities Covered: Good manufacturing practice labeling

Process:

Notify Dept. prior to start up of new processing facility.

Fees:

N/A

Other Information: Inspection of processing/sanitation is required by State/Federal law.

5. CERTIFICATION OF AUTHORITY - (Corporations incorporated in another state and want to do business in Wyoming)

Issuing Agency: $\quad$ Secretary of State/Corporations Division

Capitol Bldg, Rm 110

Cheyenne, WY 82002

(307)777-7311 FAX (307)777-5339

Statutory Reference: $\quad$ W.S. 17-16-1501 \& 17-16-1503

Regulatory Reference:

Activities Covered: Doing business in Wyoming

Process:

Complete application for authority form from Secretary of State's office. Submit with signed registered agent consent (form also available with certificate of authority form), certificate of good standing or existence from the state of incorporation and $\$ 80$ filing fee to Secretary of State.

Fees: $\quad \$ 80$

Other Information:

6. CORPS OF ENGINEERS SECTION 10/404 PERMIT

Issuing Agency: Omaha District, Corps of Engineers,

Cheyenne Regulatory Office

2232 Dell Range Blvd., Suite 210

Cheyenne, Wyoming 82009

(307)772-2300 FAX (307)772-2920

Statutory Reference: $\quad$ Rivers \& Harbors Act (33 U.S.C. 403).

Clean Water Act (33 U.S.C. 1344)

Regulatory Reference: 33 CFR Parts 320-330

Activities Covered: $\quad$ Placement of dredged or fill material into or excavation of material from Wyoming water bodies and wetlands 
(section 404-CWA). Also - all activities impacting navigable water bodies (Flaming Gorge Reservoir) Section 10 Rivers \& Harbors Act.

Process:

Contact Cheyenne Regulatory Office for permit applications, jurisdictional determinations, and authorization requirements before planning or undertaking any activity in State waters and including wetlands.

Fees:

$\$ 100$ for industrial or commercial activities requiring individual permit. $\$ 10$ to private property owners. No fee - Governmental agencies.

Other Information: Section 404 CWA - Joint permitting Responsibilities with Wyoming Department of Environmental Quality Water Quality Division in accordance with their authority under section 401 of the Clean Water Act.

\section{PERMIT TO CONSTRUCT}

Issuing Agency: Department of Environmental Quality

Water Quality Division

Herschler Building - 4th Floor West

Cheyenne, WY 82009

(307)777-7781 FAX (307)777-5973

Statutory Reference: WY Environmental Quality Act

Regulatory Reference: Water Quality Rules - Chap III

Activities Covered: Construction of pollution control facilities.

Process:

File application with plans and specifications signed by professional engineer registered in Wyoming.

Fees:

None

Other Information:

8. NATIONAL POLLUTANT DISCHARGE ELIMINATION SYSTEM PERMIT Issuing Agency:

Department of Environmental Quality

Water Quality Division

Herschler Building - 4th Floor West

Cheyenne, WY 82009

(307)777-7781 FAX (307)777-5973

Statutory Reference: WY Environmental Quality Act 
Regulatory Reference: Water Quality Rules - Chap II

Activities Covered: Discharge to surface waters.

Process:

File NPDES application 180 days prior to anticipated start of discharge. Thirty day public notice with potential for public hearing on contested issues.

Fees:

None

Other Information: 


\section{SOUTH DAKOTA}

1. NATIONAL POLLUTANT DISCHARGE ELIMINATION SYSTEM (NPDES) PERMIT Issuing Agency: $\quad$ U.S. EPA, Region VIII, Water Management Division, NPDES Branch

One Denver Place - Suite 500,999 - 18th Street,

Denver, CO 80202-2466

(303)293-1432 FAX (303)294-1386

Statutory Reference: Section 402 of the Clean Water Act

Regulatory Reference: $\quad 40$ CFR 122

Activities Covered: $\quad$ Aquaculture facilities as defined in 40 CFR 122.24 and 122.25 that discharge to waters of the U.S. and construction activities disturbing 5 or more acres.

Process: $\quad$ 1) Review application 2) Visit site 3) Draft permit

4) Public notice permit, hold hearing, if requested 5) Issue permit

Fees: $\quad$ None

Other Information: Plans and specifications for any wastewater treatment facilities must be approved by the Dept. of Environment and Natural Resources prior to construction. The state is working toward receiving NPDES and National Pretreatment Program delegation from EPA by July of 1993. Upon delegation, state issued permits will replace EPA issued permits. There will be an annual permit fee for state issued permits. Upon delegation, 401 water quality certification will also be done by the state.

\section{RESIDENT WHOLESALE BAIT DEALER}

Issuing Agency: Department of Game Fish and Parks

Licensing Office

412 West Missouri

Pierre, SD 57501

(605)773-3393 FAX (605)773-6245

Statutory Reference: SDCL 41-6-44

Regulatory Reference: $\quad$ ARSD 41:09:04

Activities Covered: Statutes: Privileges granted - Rules - Violations. Rules:

Taking, possession, transportation, fees, water open to fishing, legal equipment, endangered species records and violations 
Process: Application reviewed and reports received

Fees: $\$ 200 /$ year

Other Information:

3. HEALTH CERTIFICATE AND IMPORT PERMIT

Issuing Agency: Animal Industry Board 411 South Fort Street

Pierre, SD 57501

(605)773-3321 FAX (605)773-5459

Statutory Reference: SOCL 40-5-8

Regulatory Reference: $\quad$ 12-68:06

Activities Covered: Importation

Process:

Contact state veterinarians office at Animal Industry Board.

Fees:

None

Other Information:

4. PRIVATE FISH HATCHERY LICENSE

Issuing Agency: Dept. of Game, Fish and Parks

Licensing Office

412 West Missouri

Pierre, SD 57501

(605)773-3393 FAX (605)773-6245

Statutory Reference: $\quad$ SDCL 41-6-39

Regulatory Reference: ARSD 41:09:07

Activities Covered: Statutes: Private Hatchery license: Privileges granted violations as misdemeanor. Rules apply to persons licensed to operate a private fish hatchery, license fees and expiration, sale of fish, records and reports.

Process:

Application review and site visitation prior to issuance of initial license.

Fees:

$\$ 50 /$ year

Other Information: Technical assistance provided on limited basis. 


\section{SALMONID IMPORTATION PERMIT Issuing Agency: Department of Game, Fish and Parks 445 East Capital Pierre, SD 57501 (605)773-4508 FAX (605)773-6245}

Statutory Reference: $\quad$ SDCL 41-13-3.1

Regulatory Reference: $\quad$ ARSD 41:09:08

Activities Covered: Statute: Importation of fish or eggs of the family salmonidae. Rules: salmonidae importation prohibited without permit, disease certification required, packing, inspection, violations and exempt shipments.

Process: $\quad$ Application requires current fish disease certification from egg and/or fish source by US F\&WS certified pathologist to be free of emergency prohibited fish pathogens or diseases listed.

Fees: $\quad$ None

Other Information: Technical assistance provided to in-state private hatchery operator in obtaining disease certification for out of state shipments.

\section{RETAIL BAIT DEALER LICENSE}

Issuing Agency: Department of Game, Fish and Parks

Licensing Office

412 West Missouri

Pierre, SD 57501

(605)773-3393 FAX (605)773-6245

Statutory Réference: SDCL 41-6-45

Regulatory Reference: $\quad$ ARSD 41:09:04

Activities Covered: $\quad$ Statutes: Privileges granted, Sales prohibited - Rules - age exemption. Rules: Taking, possession, transportation, holding fees, public water open to baitfishing, equipment records and violations.

Process: $\quad$ Applications reviewed and reports received.

Fees: 
Other Information:

7. NONRESIDENT WHOLESALE BAIT DEALER LICENSE

Issuing Agency: Department of Game, Fish and Parks

Administration/Licensing

412 West Missouri

Pierre, SD 57501

(605)773-3393 FAX (605)773-6245

Statutory Reference: $\quad$ SDCL 41-6-44.1

Regulatory Reference: $\quad$ ARSD 41:09:04

Activities Covered: $\quad$ Statute: Privileges granted - Rules - violations. Rule: Possession, transportation, fees, records required, and violations.

Process: $\quad$ Applicants must come from states that provide equal opportunity to South Dakota residents. Application reviewed and approved annually.

Fees:

$\$ 400 /$ year.

Other Information:

8. EXPORT BAIT DEALER LICENSE

Issuing Agency: Department of Game, Fish and Parks

Licensing Office

412 West Missouri

Pierre, SD 57501

(605)773-3393 FAX (605)773-6245

Statutory Reference: $\quad$ SDCL 41-6-45.1

Regulatory Reference: ARSD 41:09:04

Activities Covered: Statutes: Privileges granted - Rules - violations. Rules: Possession, transportation, fees, records, and reports.

Process:

Applications reviewed along with annual reports.

Fees:

$\$ 300$

Other Information:

9. CONTRACT COMMERCIAL FISHING ROUGH AND BULLHEADS

Issuing Agency: Department of Game, Fish and Parks 
Wildlife

412 West Missouri

Pierre, SD 57501

(605)773-4508 FAX (605)773-6245

Statutory Reference: $\quad$ SDCL 41-13-7 thru 10

Regulatory Reference:

Activities Covered: Statutes: Supervision, bond required, equipment tagging, sale and transportation of fish, deposition of game fish taken.

Process:

Contracts on specific waters for specific times and amounts of fish.

Fees: $\quad 0-4$ cents per pound of fish harvested dependent on species.

Other Information:

10. HOOP NET, TRAP AND SETLINE LICENSE

Issuing Agency: Department of Game, Fish and Parks

Licensing Office

412 West Missouri

Pierre, SD 57501

(605)773-3393 FAX(605)773-6245

Statutory Reference: $\quad$ SDCL 41-6-38

Regulatory Reference: $\quad$ ARSD 41:07:08

Activities Covered: Statute: Privileges tagging of gear - violations. Rules: license eligibility and fees, amount and sizes devices - size limit species - sales - records areas open to fishing.

Process: - License application

Fees: $\quad \$ 10 /$ net, $\$ 5 /$ setline

Other Information: 